
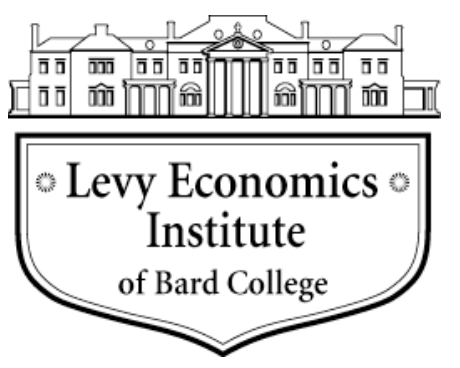

Working Paper No. 605

\title{
Detecting Ponzi Finance: \\ An Evolutionary Approach to the Measure of Financial Fragility
}

\author{
by
}

Éric Tymoigne

Lewis and Clark College

and Levy Economics Institute

June 2010

The Levy Economics Institute Working Paper Collection presents research in progress by Levy Institute scholars and conference participants. The purpose of the series is to disseminate ideas to and elicit comments from academics and professionals.

Levy Economics Institute of Bard College, founded in 1986, is a nonprofit, nonpartisan, independently funded research organization devoted to public service. Through scholarship and economic research it generates viable, effective public policy responses to important economic problems that profoundly affect the quality of life in the United States and abroad.

Levy Economics Institute

P.O. Box 5000

Annandale-on-Hudson, NY 12504-5000

http://www.levyinstitute.org

Copyright (C) Levy Economics Institute 2010 All rights reserved 


\begin{abstract}
Different frameworks of analysis lead to different conceptions of financial instability and financial fragility. On one side, the static approach conceptualizes financial instability as an unfortunate byproduct of capitalism that results from unpredictable random forces that no one can do anything about except prepare for through adequate loss reserves, capital, and liquidation buffers. On the other side, the evolutionary approach conceptualizes financial instability as something that the current economic system invariably brings upon itself through internal market and nonmarket forces, and that requires change in financial practices rather than merely good financial buffers. This paper compares the two approaches in order to lay the foundation for the empirical analysis developed within the evolutionary approach. The paper shows that, with the use of macroeconomic data, it is possible to detect financial fragility, especially Ponzi finance. The methodology is applied to residential housing in the U.S. household sector and is able to capture some of the trends that are known to be sources of economic difficulties. Notably, the paper finds that Ponzi finance was going on in the housing sector from at least 2004 to 2007, which concurs with other works based on more detailed data.
\end{abstract}

Keywords: Financial Fragility; Financial Crisis; Financial Policy; Minsky

JEL Classifications: E12, E32, G01 


\section{INTRODUCTION}

The contemporary world economy has recorded a significant increase in financial instability relative to the past. While currency crises are about as frequent, banking crises and twin crises (simultaneous banking and currency crises) have become much more frequent relative to the Breton Woods era. Moreover, while banking crises and currency crises have become individually less destructive than during the interwar period, twin crises are currently the most destructive (Bordo et al. 2001).

The increasing instability of the world economy has progressively attracted the interest of economists, and since the Mexican and Asian crises of the mid-1990s a growing body of work has developed to predict currency, debt, and banking crises. Overall, however, most of the reviews of the literature conclude that models have been quite ineffective because they are noisy and do not perform better than an educated guess. Moreover, the time frame over which the models are able to provide a correct prediction is too short to leave enough time to steer the economic system out of troubles. As argued below, one of the central causes of this outcome is an underlying theoretical approach in which money and finance are difficult, if not impossible, to include in a meaningful fashion. As a consequence, financial instability is an exogenous phenomenon that occurs because of random shocks in the economy, because of individual or market imperfections, or because of improper government policies.

This paper approaches the problem of financial instability differently. Following Minsky's framework, financial instability is conceptualized as the result of the inner working of economic mechanisms, and periods of economic stability generate economic instability. More precisely, long periods of economic growth with minor recessions create a financial environment prone to debtdeflation processes. As a consequence, the time to worry about financial instability is not just when the economy is on the brink of collapse, but rather all along.

Thus, if one follows Minsky's approach the point becomes to detect the different degrees of financial fragility rather than financial crises. Stated alternatively, the point becomes to check the evolution of financial positions and funding practices, rather than to predict the occurrence and the timing of crises. As shown below, several empirical analyses have already been performed to detect financial fragility and this paper aims at complementing what has been done by focusing on the detection of Ponzi processes, i.e., economic activities relying on Ponzi finance. It is argued that 
Ponzi processes can be detected well in advance of a crisis when banks' balance sheets look strong, net worth of households and businesses is rising, and unemployment is declining.

The first of part of the paper compares two conceptual frameworks and reviews the literature on the detection of financial fragility. The second part of the paper defines precisely what Ponzi finance is and what it is not, and provides a framework to empirically detect Ponzi finance processes. The third part of the paper implements the approach developed in parts one and two by looking at residential housing finance in the U.S. household sector.

\section{DETECTION OF FINANCIAL FRAGILITY AND FINANCIAL CRISIS: SETTING THE FRAMEWORK OF ANALYSIS}

\subsection{Financial Fragility: What Is It?}

As Schroeder (2009), Hume and Sentance (2009), and Tymoigne (2007 and 2009a) note, the conceptualization of financial fragility heavily depends on the underlying theoretical framework. There are two conceptions of financial fragility: one that relies on a state and conflates financial fragility with financial crisis, and another that rests on a process and makes a clear difference between financial fragility and financial instability.

\section{Financial Fragility as a State}

In the standard mainstream models, money and finance are neutral and financial markets are efficient, so until the 1990s there was very little interest in the study of financial crises (Gertler 1988). In the1990s, Mishkin (1991), Bernanke and Gertler (1990), and Kiyotaki and Moore (1997) provided a theoretical foundation based on asymmetry of information to understand what happens during a financial crisis. More recently, Suarez and Sussman (1997 and 2007) have completed this imperfection view of financial crises by focusing on the reversion mechanisms instead of the propagation mechanisms. The imperfection view can be complemented by the monetarist view of financial crises (Schwartz 1988 and 1998) and by the irrational approach developed by behavioral economics (Shiller 1999; De Bondt and Thaler 1985 and 1995). The former states that financial crises are due to the incompetence of policymakers, and the latter states that behavioral "biases" of individuals contribute to the emergence of crises. As a result of individual imperfections, market imperfections, and poor discretionary policymaking, market mechanisms amplify, rather than 
correct, the effects of shocks on the optimal saving-investment equilibrium, which leads to bubbles and financial crises.

Recently some mainstream economists (Bårdsen, Lindquist, and Tsomocos 2006; Hume and Sentance 2009) have critiqued the current mainstream macroeconomic models from their incapacity to account for financial fragility in an endogenous fashion. For example, they note that the Walrasian general equilibrium framework is "a model of an exchange economy [so] we cannot analyse the relationship between financial instability and economic growth" (Bårdsen et al. 2006: 26). This is typical of models like Kiyotaki and Moore (1997), which study the impacts of an exogenous productivity shock on the interaction between asset prices and credit constraints within the context of an elaborated peasant economy, i.e., a corn model in which monetary considerations do not influence economic activity. All this opens the door to several issues.

First, while the goal is to study the emergence of financial fragility, the latter is introduced awkwardly in models. A direct way to do this is to introduce an exogenous probability of crisis:

In the first period trades by all agents take place against a background of uncertainty about the economic conditions (the state of nature) that will prevail in the second period. Agents are, however, assumed to have rational expectations, and to know the likelihood of good or bad states occurring when they make their choices in period one. In period two the actual economic conjuncture is revealed and all uncertainty is resolved. (Aspachs et al. 2006: 42)

There is no relationship between the decisions people make, especially their financing and funding decisions, and the probability of occurrence of a financial crisis. The latter is exogenously imposed by the modeler and "nature decides which of the [economic state] occurs" (Goodhart, Sunirand, and Tsomocos 2004: 5). A more elaborated version of this type of model may include endogenous subjective probabilities of crisis, but the actual probability of crisis is still given (Guttentag and Herring 1984). As a consequence, there is no explanation of how the economy enters a crisis beside bad luck or shocks. Episodes of financial instability are rare random events that happen as infrequently as "giant tsunami," as Alan Greenspan characterized the Great Recession, and that are not induced by the inner working of the economy.

A second way to introduce financial fragility is by endogeneizing the probability of failure by introducing imperfections among individuals and markets. For example, incomplete contracts 
and asymmetries of information create an agency-problem between borrowers and lenders, and greater borrowing increases moral hazard (Bernanke and Gertler 1990; Stiglitz and Weiss 1981). One can endogeneize this approach by making business success a positive function of individual effort and by assuming that the latter creates disutility. This is combined with the idea that high prices create an incentive to overproduce and so lower net gain, which, in turn, promotes lower individual effort and so higher probability of failure (Sussman and Suarez 1997 and 2007). There is, however, a relatively simple way to solve the problem by improving information and contracts. A better contract or a better capacity to enforce it in court would get rid of the problem of instability. In addition, this explanation is limited in its relevance because bankers are experts in detecting problems and know that borrowers inflate their views. It is actually one of the central jobs of bankers to adjust the expectations of borrowers to realistic levels. In this case, a change in banking structure and incentives is probably a better explanation of instability (Wray and Tymoigne 2009; Suzuki 2005; Knutsen and Lie 2002). Moreover, if the point is to conceptualize fraud, we know that the looting logic is very different from the traditional way of doing business. For fraudulent schemes, negative net worth is not a problem, creative accounting is the rule, and maintaining a going-concern is no longer an objective. As a consequence, individual effort is no longer oriented toward promoting the going-concern of a company, but, rather, focuses on short-term gains. In this case, the success of the fraud scheme is not measured by the success of an economic project (Akerlof and Romer 1993; Black 2005). Finally, even among honest individuals, the success of an enterprise may only be partially related to individual effort, and variables outside the realm of control of individuals usually have a determining influence on the success of a business. Thus, financial fragility is not mainly an agency problem, but rather a macroeconomic problem, and imposing a state of imperfection forces the issue and dramatically narrows policy insights and the practically of the results obtained.

A second issue with the static view of fragility is that most authors tend to view fragility and instability/crisis as the same thing. As shown below, this can be seen more clearly when empirical analyses are performed in which authors tend to use declining real GDP growth, rising spreads, lower profit, and other manifestations of instability as a measure of fragility. As a consequence, the statistical detection of financial problems becomes close to coincidental, if not fully coincidental, with financial instability. However, by the time people start to worry about a potential financial crisis it is too late - problems have accumulated beyond easy fixes and a crisis becomes unavoidable. Problems that lead to a crisis emerge long before the economy gets into troubles. It is 
when GDP is growing steadily on a noninflationary path, profits are strong, and loan delinquency is low that economists should be worried. In addition, by the time financial fragility has grown to the point that financial instability is highly probable, there are many potential sources of crisis. At that point, it is useless to spend much time on trying to figure out the sources and the timing of a crisis. Those questions become irrelevant for policy purposes. To make an analogy, if there is a major mechanical failure that threatens the drivability of a car, one does not care about the timing of the failure (today? tomorrow? next week?), nor about how it will occur. One immediately goes to fix the car (possibly by towing it) even if this proves costly because this is always much cheaper than a crash and potential loss of life.

A third problem with the static view of financial fragility is that the theoretical treatment of banks and monetary and financial relations drastically alters the practicality of the model for policy purpose, as well as its theoretical insights. This is especially so for models that analyze financial crises in overlapping generation models. First, everything is done in real terms with people putting their real capital ("savings") in banks for future uses when they retire; meanwhile banks lend the real capital. In capitalist economy, all economic decisions are done in monetary terms, monetary returns and losses affect decisions, and banks are not intermediaries. Banks do not lend anything they have, they grant monetary advances first and then cover any reserves needs in excess of reserve holdings by selling assets or borrowing reserves, whichever is the cheapest among the available sources. Having a stable source of depositors makes the cost of acquiring reserves cheaper, but in no way constrains the advances of funds by banks, which is done ex-nihilo by crediting the account of borrowers. In addition, the monopoly supplier of reserves is the central bank so savers have no means to acquire reserves until the central bank injects them; leaving cost aside, banks could obtain all their reserves from the central bank and have no use for savers. However, in the models, the central bank is usually absent and the source of the initial allocation of financial capital (if any) is left unexplained. Finally, the debt relations induced by the presence of monetary instruments are ignored and, instead, a monetary economy is conceived as a barter economy with a special commodity used as means of exchange.

All these issues become central when the mathematical model needs to be closed. Indeed, the mathematical closure of some models usually requires the full liquidation of banks when the last generation retires (e.g., Aspachs et al. 2007). This is a major financial crisis in the model, but modelers do not call it that. Indeed, all transactions are in real terms so the "liquidation" of banks really only involves a transfer of the goods produced that period to the depositors. The production 
process allows the generation of the expected real return unless the "crisis state" occurs (in terms of production), but general liquidation does not in itself affect the return obtained; therefore, if the "good state" occurs the physical return will be provided and the last generation is fine. We have known since Fisher's debt-deflation theory that the economic system does not work that way. All financial obligations are dealt in monetary terms, and a general liquidation of those obligations has a dramatic impact on the nominal and real return obtained. Not only does a state of general liquidation prevent the distribution of what has been produced, but also debt deflation makes the matter worse because it prevents the production of goods in the first place, even if the "good state" occurs (e.g., the weather turns out to be perfect for a great yield and harvest). Thus, analyzing financial crisis through a barter peasant economy is a simplifying assumption that is inappropriate for the study of the economy in which we live and for the problem at hand.

\section{Financial Fragility as a Process}

Hume and Sentence (2009) note that Minsky provides an explanation of financial fragility that is fully endogenous and that is extremely useful to understanding the occurrence of financial instability. While Aspaschs et al. (2006) classify Minsky into the information-based approach to financial fragility, this is clearly not the case. Economic agents in the Minskian framework are mostly rational and bubbles, asymmetries of information, and other imperfections are not at the core of his analysis. The boom period in the Minskian framework is a short period and is only there to give the coup de grâce; problems emerge and grow during the long period of stability when the economy is performing well and only recorded minor recessions:

Even though a prolonged expansion, dominated by private demand, will bring about a transformation of portfolios and changes in asset structures conducive to financial crises, the transformations in portfolios that take place under euphoric conditions sharply accentuate such trends. [...] Thus, the theory of financial stability takes into account two aspects of the behavior of capitalist economy. The first is the evolution of the financial structure over a prolonged expansion [...]. The second consists of the financial impacts over a short period due to the existence of highly optimistic, euphoric economy; the euphoric economy is a natural consequence of the economy doing well over a prolonged period. (Minsky 1972: 119) 
In this approach, financial fragility builds up when bank profits are rising, net worth is growing, default rates are low, interest rates are stable, and the economy is growing steadily. Thus, contrary to the static approach to financial fragility, one cannot use mainly rising interest rate spreads, rising default rates, lower bank profits, and other indicators of lower economic growth or rising nonperforming loans to detect financial fragility. Instead, given that the financing and funding practices of economics are at the core of financial fragility, they should be scrutinized very carefully. The goal, then, is to capture this worsening in the financing and funding quality (rather than quantity) early when everything is going well, in order to take preemptive measures by determining the cause of the worsening.

This is clearly illustrated by the last housing boom. As shown in figures 1 and 2, from 2003 to 2006 the serious delinquency on all mortgages declined-especially so for subprime mortgages - and household net worth grew fast. However, we know today that all this was made possible by a Ponzi process in the housing sector in both the prime and nonprime mortgage lending (Tymoigne 2009b). The expectation that home prices would rise forever created an expectation that cheap refinancing would be always available.

\section{Figure 1. Serious Mortgage Delinquency}

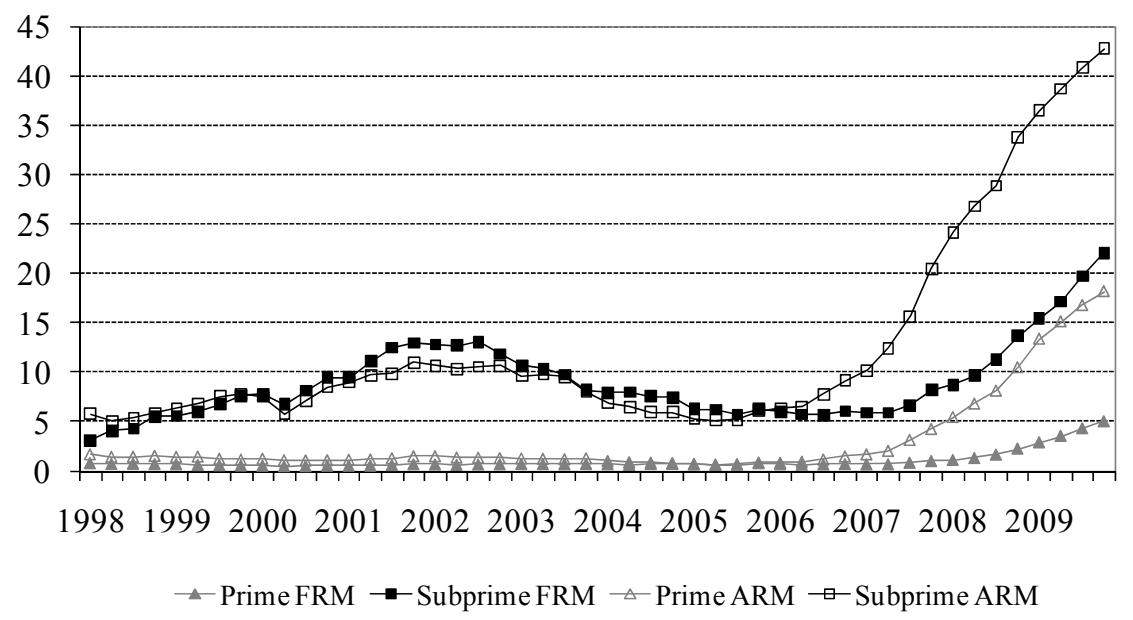

Source: Mortgage Bankers Association.

Combined with the low-doc and low-cost effects of mortgages, the previous states of expectations led to a decline in monthly mortgage payments and growing refinancing, which, in turn, led to declining default rates for three years. However, this improvement was only temporary 
because it was based on unsustainable funding practices. By the time default rates grew, it was too late to do anything substantial that could avoid the crisis. Most of the damages had been done. In fact, rising default rates became themselves coincidental with the crisis and so a measure of the crisis rather than a predictor of the crisis.

Thus, the point of detecting of financial fragility is to avoid dramatic scenarios like these by limiting the impact of the business cycle on the deterioration of funding positions and vice versa. From 2003, measures should have been taken to constrain the growth of the mortgage finance by preventing financial institutions from providing mortgages to noncreditworthy customers, and from financing and refinancing creditworthy borrowers into low-quality mortgages. The growth of home equity loans should also have been constrained to make sure that it kept pace with households' income rather than home prices.

In addition, the evolutionary approach to financial fragility makes a clear difference between financial fragility and financial instability. The more financial fragility is allowed to develop, the more severe financial instability will be. Financial fragility is defined as the dependence of financial positions (balance sheets, income account, cash-flow accounts) on refinancing and liquidation. Financial instability refers to the propensity of financial fragility to affect the economic process; it ultimately materializes itself by a debt-deflation process: "An increase in the ratio of Ponzi finance, so that it is no longer a rare event, is an indicator that the fragility of the financial structure is in a danger zone for a debt-deflation" (Minsky 1986: 379).

Financial fragility generates financial instability on the upside (bubble and inflation) and on the downside (financial crisis and debt deflation). Thus, the goal becomes to preempt financial instability by constraining the growth of financial fragility.

Following Minsky's framework, the degree of financial fragility can be defined by three categories: hedge, speculative, and Ponzi finance. Each of these categories is expected to require a certain level of defensive position-making operations, i.e., refinancing operations and/or liquidation to pay debt commitments. Note that this categorization is not a measure of the use of external funding, i.e., of the size of leverage, but rather a measure of the quality of the leverage. Indeed, hedge financing may involve a heavy use of external funds, but is not expected to require any defensive position-making operations. Speculative finance is expected to require a rolling over of the capital component of financial obligations; Ponzi finance is expected to require growing position-making needs given existing outstanding debts because capital and income components of financial obligations are expected to be greater than cash inflows from normal economic operations. 
According to the financial instability hypothesis, over time market-based economies tend to rely more and more on Ponzi finance. Thus, any slowing down in the growth of asset prices that sustains the net worth of individuals or the nonrealization of expected income threatens the willingness of banks to refinance borrowers. As shown below, these categories suggest means to empirically measure financial fragility that are quite different from the static approach.

One should note that these categories do not apply to monetarily sovereign governments, i.e., governments that issue securities denominated in their own currency and that do not promise to convert their currency in anything else. Indeed, in that case, default is impossible and liquidity problems are also impossible (at least for economic reasons); hedge financing applies all the time. In addition, under any monetary system, government spending financially helps the private sector by injecting cash flows, providing liquid assets, and raising the net worth of some or all private economic agents. This suggests several points to be aware of when doing an empirical and conceptual analysis of fragility.

First, if one is purely concerned with the private-sector fragility, national accounting shows that government deficits directly help to improve the financial strength of the former sector. Second, government deficits may be a source of instability under stringent exchange rate regimes or if the government issued securities in foreign-denominated currency. In those cases, the three categories of financial fragility apply because there is a refinancing risk and a liquidity risk induced by the need to get a currency that the government does not issue. The more stringent an exchange-rate regime, the more problematic government deficits and current account deficits; indeed, they create potential speculative attacks and increase position-making risk for government. For example, this was observed recently in Greece (who lost its monetary sovereignty to the eurozone) and Argentina (who gave up its monetary sovereignty for the maintenance of a currency board). However, government surpluses can also create problems for the maintenance of a currency regime by significantly weakening the financial positions of the private sector. Finally, under stringent currency regimes, government finances may be constrained in such a way that fiscal deficits and lender of last resort policy are limited, which increases the instability of the private sector. Overall, therefore, it is important to make a difference between sovereign and nonsovereign monetary regimes for the analysis of financial fragility. 


\subsection{Empirical Work on Financial Fragility}

\section{Static Approach: Predicting Financial Crises}

Economists following the static approach have developed "early warning systems" (EWS) through many different methods. Some of them have relied on microeconomic data, others have relied on macroeconomic data, and some of them have combined both sets. Some of them have relied on regression techniques to determine the probability of a crisis while others have used indicators to signal a problem.

EWS were first developed to complement on-site supervision of banks in order to help supervisors to eliminate "dishonest, incompetent, and inequitable elements of banking" (Sinkey 1977: 40). Macro-oriented EWS were first developed to deal with currency crises in emerging economies in the mid-1990s and were rapidly extended to the detection of banking crises, especially in emerging countries where traditional indicators of banking supervision (CAMELS) have not been very reliable (Rojas-Suarez 2001). A good review of the literature is provided by Gaytàn and Johnson (2002), International Monetary Fund (2009), Schroeder (2008), Klein and Shabbir (2003), Grabel (2003), Berg and Borensztein (2004), Edison (2000), and Lestano and Kuper (2003). Overall all those papers conclude that EWS fail to perform better than an educated guess. Indeed, there are several issues with all those models and the goal they want to achieve.

First, the purpose of EWS is to predict the occurrence of a crisis and the most ambitious authors also want to determine the timing and depth of a crisis (e.g., Rose and Spiegel 2009). Leaving aside the last two issues, EWS compete for more accurate predictions by looking for better leading indicators of crisis. For example, Demirgüç-Kunt and Detragiache (1998), Marlor (1997), Reinhart and Rogoff (2007), Kaminsky and Reinhart (1999), Goldstein, Kaminsky, and Reinhart (2000), and Bordo et al. (2001) note that it looks like macroeconomic variables (rising real interest rates, lower economic growth), financial variables (rising M2/reserve, rapid growth in bank credit allocated to private sector, growing nonperforming loans, rising asset prices), industry variables (competition, influx of customers), and regulatory variables (existence of a deposit insurance scheme, tax structures, and reserve requirements that encourages maturity mismatch) are highly correlated with the occurrence of a banking crisis. There is, however, no theoretical framework that coherently ties these variables together. We, therefore, end up with a patchwork of variables added on the top of each other to reproduce past crises and get better prediction, without any general coherent explanation. The end result is an econometric model that provides some fitting of data, but that is hard to use out of the sample to accurately predict other crises. 
Moreover, as Bell (2009) notes, one should not only be concerned with crises, but also with financial fragility, i.e., how the possibility of a crisis emerges. That implies looking at the process that makes the occurrence of a crisis possible, but this issue is not dealt with by those models. This can be best illustrated by the signal approach developed by Goldstein, Kaminski, and Reinhart (2000). Each variable is transformed into a dummy variable that takes a value of 1 if the variable passes an arbitrary threshold that reflects financial fragility. The more variables that pass a threshold and the more dummy variables that take the value of 1 , the greater the chance of a crisis. However, the signal approach does not account for the impact of correlated movements among explanatory variables. Indeed, more important than the threshold is how explanatory variables move relative to each other and specific comovements should be assigned a dummy variable. This implies having a theory about which comovement matters for financial fragility.

Second, an implication of the previous weakness is that most variables included in EWS behave in a way that is coincidental with crises. Aspachs et al. (2007) use the rising probability of default of households and lower bank profit to measure financial fragility and use decline in real GDP to measure financial instability. Gonzalez-Hermosillo (1999) and Demirgüç-Kunt and Detragiache (1998) note that rising nonperforming loans are a sign of crisis or near bank failure. Davis (1995) defines fragility through rising default rate and foreclosure. In all those cases, it is not surprising to find a strong correlation between fragility and crises because the variables used to define fragility are a manifestation of a crisis. In addition, foreclosures and defaults, especially rapidly rising foreclosure and defaults, are a consequence of a crisis rather than a cause of it.

Given the way fragility and instability are defined and measured, there are at least three issues that emerge. First, there is an endogeneity issue at stake in econometric models of EWS. Some authors do recognize this issue, but it is hard to deal with this problem unless one clearly separates fragility and instability. A good definition of financial fragility would be able to detect problems when everything is going well — default rates are stable or declining, nonperforming loans are stable or declining, GDP is growing, among others. As second issue is that the capacity to provide a signal of a problem before a crisis is evident is very limited. Lestano and Kuper (2003) note that banking crisis models produce the best signals two or three quarters ahead. While Goldstein et al. (2000) claim that this is good enough (they find an average of 11 months lead time for banking crises), this is quite short for policy purposes to be able to deal with the problems. As a consequence, by the time a crisis is predicted, most of the damages have already been done and/or it is extremely difficult to implement policies that can change the course of the economy. Third, for 
policy purposes, by associating economic success and financial stability with rising profits and declining default rates, one creates a strong intellectual barrier against preemptive actions.

Policymakers become highly reluctant to intervene to eliminate unsustainable financial practices of "successful" businesses. For example, Black (2005) notes that tremendous pressures were put on examiners not to close fraudulent S\&Ls because their high profitability made them models for the industry.

A third problem comes from the fact that some models use mostly security price data to predict crises. For example, Segoviano and Goodhart (2009) use CDS spreads and out-of-themoney option prices to measure the probability of default of banks; they also note that CDS spreads slightly precede bank crises. While they recognize that the price of securities is volatile and may involve illiquid markets, they argue that the trend of prices gives a good signal of future crises. Indeed, in their framework, financial-market participants are forward-looking and mostly driven by fundamental analysis, and financial markets allow participants to allocate efficiently their resources. Thus, "if markets are efficient," an adverse price signal for a specific sector of the economy provides a clear sign that some financial problems are upcoming (Fell and Schinasi 2005: 114; International Monetary Fund 2009). This, however, is a big "if" and there are several issues with the use of market-price data. First, stockholders that hold CDS on their own company may have an incentive to see their company default in order to receive payments on the CDS (Hu 2008; Hu and Black 2008); therefore, CDS spread may go up not because a company is financially unsound, but because CDS holders try to promote default. Second, Fell and Schinasi (2005) note the use of market data by regulators creates a circularity between regulators and market participants when pricing securities. Third, it is well-known that financial-market participants tend to have a procyclical view of risk and so not to forecast crises until they are evident; therefore, market data tend to move only very late when the future occurrence of a crisis is obvious. Indeed, not only are there socio-psychological aspects at play that limit foresight, but also there are economic interests in ignoring the accumulation of problems even if information is costless to obtain (Galbraith 1961; Schinasi 2006; Tymoigne 2009a and 2009b). This tendency has all the more chance to develop in periods of a strong increase in financial fragility when a lot is at stake if the financial scheme collapses. Finally, the efficient market theory assumes that finance is a veil and that the liability structure sustaining an economic process is not relevant. However, the efficient allocation may be driven by a Ponzi process and in this case financial fragility builds up even if there is no 
misallocation or bubbles. This was observed very clearly during the recent housing boom, when prime borrowers were involved in Ponzi finance.

A fourth problem with the static approach is that, by focusing purely on the prediction of crises, much of the effort is spent on first getting leading indicators that provide a good prediction and second looking for "all plausible sources of risk to financial stability," especially those "that could prove to be systematically relevant" (Fell and Shinasi 2005: 114). In fact, there is an obsession with the measurement of probability and sources of risk, as well as the size of expected downturn. However, this is a rather futile exercise that loses sight of the broader picture. When an economy is financially fragile they are many different sources of risks that can be very complex and/or impossible to measure because of lack of data. More importantly, even usual fluctuations in income, asset prices, and other variables can lead to a crisis, and the triggering of a crisis can be based on unpredictable changes in the sentiments of economic agents. As Bell (2009) notes, most banking crises involve, at least in part, random triggers that are impossible to predict. Thus, rather than focusing on predicting financial crisis (something probably impossible to do) a more productive analysis should focus on the growth of financial fragility during periods of economic stability. In that case, there may not be any immediate source of risk, but the funding practices involve future dependence on limited fluctuations in incomes and asset prices around their shortterm trend. Again the point is to detect financial fragility well before any sign of crisis is in sight in order to eliminate, or at least discourage, economic growth based on unsustainable financial practices.

Fifth, poor policy (meaning government deficit, inappropriate interest-rate setting, regulatory problems, etc.) or "shocks" are supposed to be major sources of financial instability. As a consequence, economists in this framework tend to put a lot of emphasis on government debt and to bypass the importance of private debt. Stated alternatively, a rise in government debt is seen as much more problematic than a rise in private debt and will draw concerns much earlier - in fact almost immediately. Recently, in their analysis of the crisis, Reinhart and Rogoff (2009) mostly looked at government debt while they note in passing the importance of private debt. They tend to see government deficit as a source of instability independent of the nature of the monetary system in place and there is a strong bias toward the idea that government deficit is a source of financial problems under any condition. However, a typical result found by EWS is that government surpluses are a leading indicator of banking and currency crises, which leads to puzzled observations or intricate theories to try to explain this: 
The level of fiscal balance relative to GDP appears also to be statistically significantly related to the length of the contraction, but the relationship has an economically counter-intuitive sign: a higher surplus position at the beginning of the crisis is related to a longer contraction. (Cecchetti, Kohler, and Upper 2009: 19, n. 23)

This counter-intuitive result is now well documented in the literature: many of the countries hit by a crisis actually ran a fiscal surplus, noticeably Mexico in 1994 and the Asian countries in 1997. This fact led many authors to reject first generation models of currency crises for more elaborate models in which moral hazard plays a role (a country with a government surplus is more likely to bail out risky investment projects). (Bussiere and Fratzscher 2002: 27)

Here again there is a recourse to the concepts of imperfection and agency problems.

However, the fact that surpluses are associated with crises is easily understandable, especially in the context of financial instability, if one accounts for national accounting relationships. Government surpluses drain funds out of the private sector, which leads to problems meeting debt commitments and a need to refinance and liquidate. When this involves foreign-currency denominated financial transactions, any refinancing problems are prone to generate a currency crisis and a banking crisis (Kregel 1998). Thus, a currency crisis may be led by the depressive effect of government surpluses on the finances of the private sector, rather than from a speculative attack against the government fiscal deficit.

\section{Evolutionary Approach: Capturing Financial Fragility}

In the evolutionary view of financial fragility, the possibility of a crisis is endogenous to the system rather than the result of shocks. A consequence of this framework is that the focus is not the detection of financial crises, but rather the detection of financial fragility during periods of economic stability. The point then becomes to contain the growth of leverage as soon as fragility is detected, i.e., as soon as the quality of leverage deteriorates significantly.

Moreover, as noted earlier, the impact of government deficits and surpluses on financial fragility depends heavily on the type of monetary system and on the sector analyzed. Thus, the choice of which variables to check carefully will depend heavily on the monetary regime in place as well as on the economic sector of interest. One cannot assume, like the above econometric analyses, 
that fiscal deficits are always a sign of fragility or that rising business profits are always a sign of stability and strength.

Another consequence of this view is that financial variables play a heavy role in determining financial fragility. Practically, most of the emphasis must be on variables that affect the budget constraints of economic agents, i.e., cash inflows, cash outflows, and reserves of cash and other highly liquid assets. Those are the variables that determine the dependence on refinancing and liquidation operations and so the fragility of an economic unit; as a consequence, their level, variability, and reliability should be studied carefully. In this case, rapidly rising profits, rising wealth, and rapid increases in credit may be a source of concern, especially if they occur simultaneously. Similarly, rising interest rates and government fiscal surpluses are a source of concern for the financial strength of the private sector.

Several points should be understood, however, before engaging in such analysis. First, it is best to look at how these variables behave simultaneously rather than in isolation. For example, a rising debt-to-income ratio does not necessarily mean that an economic unit is more fragile. As noted earlier, financial fragility is not a measure of the size of the leverage, but rather a measure of its quality. For example, if the average maturity of debts increases, principal payments are stretched and so debt service may be going down even though debts outstanding are rising. Thus, if possible (and this is not always available), one should look at the debt-service-to-income ratio and the amount of refinancing operations for other purposes than interest-rate refinancing (i.e., locking in a lower interest rate). Second, the on-balance accounting documents of economic units may only tell part of the story because some economic units may have major off-balance positions. Hadley and Touhey (2006 and 2007) recently noted that traditional liquidity ratios for commercial banks can be misleading because loans are no longer illiquid and core deposits are no longer the only stable source of funding. As a consequence, asset quality may no longer play a role in liquidity problems and much more emphasis should be put on cash-flow analysis in order to assess funding structures, liquidity needs and alternative sources of funds in relation to different economic and financial risks, as well as to determine contingency funding plans. This is very similar to what Hyman Minsky advocated in 1975 with conditional analysis and the emphasis on position-making operations (Minsky 1975).

Several studies have been conducted in this framework of analysis and they can be separated in two categories. The most straightforward studies analyze the trend of several variables and check how they help to explain recessions. The second set of studies uses the hedge, speculative, and 
Ponzi categories and aims at detecting one or more of these categories. In the first set of categories authors usually find that leverage increases and liquidity decreases during periods of expansion (Minsky 1977, 1984, and 1986; Sinai 1976; Niggle 1989; Wolfson 1994; Grabel 2003; Estenson 1984). ${ }^{1}$ Leverage and liquidity are measured by looking at several balance sheet ratios, like debt-toincome ratio, proportion of short-term debts, debt-service-to-income ratio, the proportion of cash, and other liquid assets. Isenberg (1988 and 1994) finds that, instead of being recorded at the aggregate level, the fragilization of the economy can be localized within the nonfinancial business sector inside the most dynamic sectors of the economy. Minsky (1984) notes that the non-financial business sector may not be at the source of the fragility, but rather the household sector or the government sector may be the main contributor to a crisis. Thus, the Great Depression was preceded by:

(1) the uses to which credit was put in the stock market, (2) the nature of household debt and in particular the household mortgage, (3) the expansions of utility-holding companies and (4) the reduction of the government debt. (Minsky 1984: 247)

Note that lower government debt (i.e., government surplus) contributes to financial fragility because it drains cash and other liquid assets from the private sector. Note also that the quality of debt in addition to its level play an important role. Indeed, at the heart of fragility are the structure of cash flow and the reliability of position-making operations. Usually financial fragility implies that cash outflows are volatile and increase dramatically after a period of time, while cash inflows are stable and maybe not denominated in the same currency.

A last point to note is that aggregate variables only give a first clue about what is going on within an economy or a sector. If some indicators behave suspiciously, it is critical to look at data more carefully at the sectorial level. In that case, not all economic activities within a sector may lead to financial fragility. For example, Minsky notes that within the household sector, usually only speculation in the stock market is routinely financed in a Ponzi way. However, mortgage finance and consumption finance can also be funded by the recourse to Ponzi and speculative finance (Minsky 1980, 1984, and 1995; Palley 1994). Thus, a good analysis of financial fragility cannot be based only on macro data, but also must look in detail at which activities contribute to the

\footnotetext{
${ }^{1}$ Suarez and Sussman (1999) also note that the ratio of interest payments to pretax capital income is a good measure of leverage and a good indicator of future crises. However, these authors do not seem to be aware of past studies in the evolutionary approach to financial fragility.
} 
fragilization of a sector. Fell and Schinasi (2005: 112) made a similar argument, however they also argue that if buffers are high enough, any type of portfolio and funding strategies should be allowed. One should remember that Ponzi finance is difficult to buffer against properly, especially when it becomes a common means of financing economic activity (Tymoigne 2009c).

The second set of authors has developed a more elaborated strategy that aims at detecting the different stages of financial fragility: hedge, speculative, and Ponzi. Some of them develop methods to detect all three stages (Schroder 2009; Foley 2003). Other authors focus their attention on detecting a specific stage of fragility, like Ponzi finance (Seccarecia 1988), or an overall index of fragility that shows overall position-making risk (i.e., refinancing risk and liquidation risk) (De Paula and Alves 2000). This paper contributes to this second branch of authors by proposing a method to detect Ponzi finance. Before this is done, however, let us review more carefully the work of those authors. This will be done in the context of carefully defining Ponzi finance.

\section{WHAT IS PONZI FINANCE?}

The first part noted that the methods and goals of the static approach and evolutionary approach to financial instability are quite different and that this is largely due to a different theoretical framework. In this and the following part, the paper focuses on the evolutionary approach of financial instability by proposing a method to measure financial fragility. In order to do so, this part defines precisely what Ponzi finance is.

The definition commonly used to define Ponzi finance is a cash-flow version, which Minsky himself used quite often. At time 0 , it is expected that the following applies until a date $n$ :

$E_{0}\left(N C F_{O t}\right)<E_{0}\left(C C_{t}\right) \forall t<n$

That is net cash inflows from core economic operations $\left(N C F_{O}\right)$ (cash inflows from core economic activities minus cash outflows from core economic activities) are expected to be too low to meet the expected cash commitments (income and capital components) on financial obligations $(C C)$. As a consequence, cash inflows from defensive position-making operations are expected to be positive and to grow relative to outstanding debts.

$E_{0}\left(C F_{P M t}\right)>0 \forall t<n$ 
That is, it is expected that larger refinancing loans and/or asset liquidations are expected to be needed and available.

Several things are important to note about this definition. First of all, it is an expectation about the future. This is important because it does not mean that right now there is a need to refinance or liquidate in order to meet cash commitments (i.e., time 0 does not need to be now). In addition, this state of expectation may never materialize, as net cash flows from core operations turn out to be higher than expected, interest rates turned out to be lower than expected, and/or borrowing for a longer maturity than expected is available. In fact, the frustration of expectations is part of the internal dynamics of the financial instability hypothesis.

The fact that expectations are involved has two implications for empirical analysis. A first implication is that Ponzi financial practices may be going on in underwriting procedures before they are captured in actual data about refinancing operations, debt levels, and other variables (Kregel 1997). Thus, data will tend to capture the development of Ponzi finance with a delay. A second implication is that any macroeconomic or sectorial analysis must be complemented by supervisory works that study the nature of the debt contracts that are being created. Suzuki (2005) and Knutsen and Lie (2002) are two very good illustrations of this point. Suzuki shows how the business practices of Japanese banks changed from cash-flow-oriented analysis to collateral-oriented analysis, from long-term partnerships with clients to short-term relationships, and from the use of know-how to the use of automated underwriting. Knutsen and Lie make a similar analysis for the Norwegian banks by showing how deregulation, tight profitability, and government policies contributed to the rapid growth of credit on the basis of collateral rather than cash flows from operation. All this was part of a deliberate strategy to grow as fast as possible. In both cases, underwriting procedures involved Ponzi finance, i.e., underwriting procedures based on expectation of refinancing and/or liquidation rather than on expectations regarding net cash inflows from operations. A similar phenomenon recently occurred in the United States in prime and nonprime mortgage finance (Tymoigne 2009b) and during the S\&L crisis (Black 2005). Both events recorded the growth of "low-doc"/“liar" loans, "low-cost"/“affordability" loans, loans that depend on refinancing to work, volume- and speed-based remuneration of loan officers, "creative" accounting techniques, and collateral-based lending (Levine and Coburn 2010).

A second implication of this definition is that Ponzi processes are, at least in part, collateraldriven. That is, the more collateral is available, the more incentive there is to be involved in Ponzi finance by taking loans based on net worth rather than on operating net cash flows. Araujo, Páscoa, 
and Martinez (2002) argue that enough collateral prevents the occurrence of Ponzi finance in incomplete markets, but this is precisely the reverse that happens once a Ponzi process is started. The recent housing boom was a good example of this when households "used the equity in their home" as a justification for greater indebtedness. The increase in leverage further boosted demand for homes, which, in turn, pushed up home prices, generating greater collateral for new lending. This positive feedback loop between home prices and mortgages could be sustained as long as bankers and households believed that home prices "always go up," which was the conventional thinking of the time. Actually, Greenspan (among others) approved of this trend by stating that rising mortgage debts among households was not a problem because home prices were going up sufficiently to allow net worth to grow:

Despite the recent high debt-to-income ratios, at least some of which is more statistical than real, the ratio of households' net worth to income has risen to a multiple of more than five after hovering around four and one-half for most of the postwar period. Taking into account this higher level of assets, all in all, the household sector seems to be in reasonably good financial shape with only modest evidence of an increased level of household financial strain. (Greenspan 2004)

For empirical purpose, this means that in order to detect Ponzi processes an important step is to check if there is a strong interaction between an asset and a specific debt within the balance sheet of a specific economic sector.

In addition, it is important to be aware that some forms of Ponzi finance are more dangerous than others, which depends on the way the economic units involved in it plan to get out of it. This, in turn, depends heavily on the types of assets involved in the Ponzi process. The most dangerous of all Ponzi processes are those for which continuous liquidations at rising prices and/or unlimited growth of refinancing are necessary for the process to continue, also called pyramid schemes; there is no way to terminate the process besides collapse or widespread restructuring of financial commitments. This type of Ponzi process is fully collateral-driven and usually involves the funding of assets that do not produce any cash flows from operation (e.g., home of residence) or that generate cash flows over which the owner has very minimal or no control (e.g., shares of companies) and so cannot be adjusted to meet the demands of debt services. Examples of those 
processes are the mortgage practices of the 2000s and the Madoff scheme (Wray 2007; Kregel 2008; Tymoigne 2009b).

A third implication of the cash-flow definition of Ponzi finance is that nominal values are crucial for the analysis of financial fragility. It is the comparison of nominal inflows and nominal outflows of cash that matters, not real interest rates, real incomes, and other real variables. This is so because cash flows may be unrelated to inflation and because financial relations are always accounted for in nominal terms, i.e., this is how the size of refinancing needs is practically determined. Thus, real interest rates may be going down, but it does not mean that nominal interest rates are going down or that the debt burden is going down. On the contrary, nominal rates may be going up, but at a slower path than inflation; higher inflation does not imply an increase in the affordability of debts because net cash inflows from operations may not be positively affected by inflation. Thus, while some authors have tested Minsky’s analysis in real terms by using real interest rates and growth of real income (Lavoie and Seccarecia 2004; Schroeder 2009), Minsky made all his analysis in nominal terms.

A fourth implication is that levels of cash flow determine the financial position of an economic unit. Some authors have defined Ponzi finance in a dynamic framework and in relation to the debt-to-income or debt-to-asset ratios; they have defined Ponzi finance as a situation in which the ratio grows forever. This is shown to occur if the growth rate of income $\left(g_{Y}\right)$ is lower than the interest rate (i), those variables being defined either in nominal terms (Domar 1944; Kregel 2004) or in real terms (Lavoie and Seccareccia 2004; Foley 2003; Schroeder 2009). There are several issues with this way of defining Ponzi finance.

First, as stated previously, the size of net worth (or the debt-asset ratio) is unrelated to the need to enter defensive position-making operations because the heart of the hedge, speculative, Ponzi (H/S/P) classification relies on cash flows and the availability of liquid assets. Economic units that are solvent on a market basis and have a growing net worth may be heavily involved in Ponzi finance. This is what was observed for the S\&Ls during the early 1980s and, as shown below, for households during the mid-2000s (Tymoigne 2009b; Black 2005). Similarly, economic units that use hedge financing may have a growing amount of debt, but this is fine as long as they can afford it. Again, at the core of the H/S/P classification is not a measure of leverage, but rather a measure of the quality of leverage. Foley (2003) and Schroeder (2009) use a narrow definition of hedge finance in which no external funding of investment is needed. However, hedge finance does not mean no external funding, it just means that debt services are expected to be fully covered by net operating 
cash inflows. Note also that hedge finance does not mean no propensity to financial instability, it only means less propensity because only declines in income or very large increases in cash commitments would create problems.

Second, note that $g_{Y}<i$ may apply even if $N C F_{O}$ (which is related to income) is greater than $C C$ (which is related to interest rate). In this case, there is no need to refinance. The growth rate condition will lead ultimately to $N C F_{O}<C C$, but this may not happen for a long time, maybe not before a debt is fully repaid or the adverse growth rate condition may be only temporary. Similarly a greater need for defensive position-making operations may arise now, even if $g_{Y}>i$, so Ponzi or speculative finance positions are not directly related to the relation between income growth and interest rate. The nominal growth condition may give a first indication about the possible financial position of an economic unit, but one needs to further check the levels of cash flows and monetary reserves.

Finally, even if one wants to check the condition in growth terms, one should include more than the interest rate because the scheduled amortization/repayment rate also matters. Indeed, Ponzi finance implies that the income and capital components of debts are greater than the income components of core economic activities. These principal repayments generate cash outflows that must be accounted for and they can be a major source of instability:

$Y<(a+i) L$

Most authors never introduce the impact of principal payment on profit and cash flow. One reason may be that debt usually grows and principal payments are always readvance; however, for bankers to agree on this, principal payments must be honored and this may not always be possible. The importance of principal repayment as a source of cash drain has been illustrated recently by the payment recasts recorded by some mortgages that will continue to grow until 2012 (International Monetary Fund 2007; Tymoigne 2009c; Dr. Housing Bubble 2009). Non- or partially amortized mortgages were also a major source of problems during the Great Depression. Thus, starting from hedge or speculative finance, a necessary, but not sufficient, condition for the preceding condition to occur is:

$g_{Y}<g_{(a+i)}+g_{L}$ 
Or, more generally (demonstration is at the end of the paper) the asymptotic condition is:

$g_{Y}<g_{a} S_{A}+g_{i} S_{I}+g_{L}$

The discrete condition is:

$g_{Y}<\left[\left(1+g_{a}\right) s_{A}+\left(1+g_{i}\right) s_{I}\right]\left(1+g_{L}\right)-1$

With $s_{A}$ the share of capital components is debt-service payments and $s_{I}$ the share of income components in debt-service payments. In addition, the value of income $(Y)$ that should be of special interest should be operative income, i.e., exceptional sources of income should be excluded from the measurement of income for the purpose of detecting financial fragility because they are part of defensive sources of cash flows.

Actually several studies in the static approach provide clues that the growth condition of Ponzi financing was validated prior to crises, but they recollect those observations without explicitly explaining their relevance. Hardy (1998) notes that rapid credit growth in one sector, refinancing granted for capitalization of interest, rising asset prices, and rising short-term funding are indicators of banking crises. Bell (2009) notes that good indicators of banking crises are rapid loan growth, slow output growth, and rising real interest rates. Bussiere and Fratzsher (2002) show that a rapid increase in credit and a high ratio of short-term-debts-to-reserves increase the probability of a currency crisis. Kaminsky and Reinhard (1999) note that a rapid increase in credit precedes banking crises. Demirgüç-Kunt and Detragiache (1998) note that low GDP growth, high real interest rates, high inflation, and a large share of credit going to the private sector are leading indicators of banking crises. Reinhart and Rogoff (2008) note that asset-price inflation, rising leverage, and slowing real GDP growth are standard indicators of crises in the United States.

A fifth implication of the definition of Ponzi finance is that the cash-flow definition is a narrow definition of Ponzi finance. The full definition of hedge, speculative, and Ponzi finance involves the structure of balance sheet, as well as off-balance-sheet positions (Tymoigne 2009a). That is, the cash-flow condition is complemented by stock conditions. For example, speculative and Ponzi finance, by definition, have a higher maturity mismatch between assets and liabilities, which most of the time means that there is a high proportion of short-term debts and low liquidity buffers. Another important characteristic of Ponzi finance is a high proportion of debts with payment 
streams that involve large sudden increases in debt services. Thus, Ponzi finance has a tendency to have a high proportion of debt with a variable interest rate, demand debts, partially amortized debts (interest only and the like), and debts with negative amortization (e.g., payment-option mortgages). All these debts involve resets of interest rates or recasts of debt services that suddenly and significantly increase the debt burden. This type of mortgages grew in proportion during the past housing boom (Tymoigne 2009b):

The apparent froth in housing markets appears to have interacted with evolving practices in mortgage markets. The increase in the prevalence of interest-only loans and the introduction of more-exotic forms of adjustable-rate mortgages are developments of particular concern. To be sure, these financing vehicles have their appropriate uses. But some households may be employing these instruments to purchase homes that would otherwise be unaffordable, and consequently their use could be adding to pressures in the housing market. Moreover, these contracts may leave some mortgagors vulnerable to adverse events. (Greenspan 2005)

According to Minsky, hedge finance involves none or very limited use of such debts. Cashflow hedge financing with a high proportion of floating-rates liabilities is considered speculative because of the dependence on changes in financial conditions (Minsky 1986: 208, n. 11). All this leads to two important points.

Firstly, when one measures expected $C C$, all the relevant debts must be included in order to define as precisely as possible the expected total cash outflow streams from financial obligations. The scope of the liabilities to include depends on the scope of the analysis. For example, if someone is interested in the overall households sector, all the actual and potential debts should be included. If someone is interested in households' investment, then homeownership and related finance are the only things to analyze.

Secondly, under Ponzi finance, it is expected that net worth and liquidity will decrease given asset value: "With speculative finance, net worth and liquidity can increase even as debt is refinanced, whereas for a Ponzi unit net worth and liquidity necessarily decrease" (Minsky 1986: $340)$.

However, given everything else, this decline in net worth and liquidity will not be recorded in data until defensive position-making needs actually occur, i.e., when $N C F_{O}<C C$. Moreover, if assets are valued on a market basis, and if their prices grow fast enough to compensate for higher 
debt or lower liquid assets, the decline in net worth can be avoided (Minsky 1964: 213ff.). In that case, the growing solvency of economy unit involved in a Ponzi process depends highly on the continuation of rising assets, rather than on the capacity to generate an income from the ownership of the asset. In fact, an economic unit involved in Ponzi finance is guaranteed to record very high short-term profits and so a very high increase in net worth for a short period. This was observed before the S\&L crisis when the most profitable thrifts were involved in massive fraudulent Ponzi finance (Black 2005). Thomson (1991) also finds that "book solvency is positively related to failure" and notes that:

One possible explanation is that banks beginning to experience difficulties improve their capital positions cosmetically by selling assets on which they have capital gains and by deferring sales of assets on which they have capital losses. (Thomson 1991: 13)

This is typical of Ponzi finance. This is an important point because, contrary to the static approach to financial fragility (and to the supervisory approach of banking), one should not wait until declining bank profitability or other signs of payment difficulties to measure fragility. A vibrant business recording high profits may hide unsustainable funding practices and the time to terminate those practices is precisely at that time. Hadley and Touhey reach similar conclusions for banks:

Liquidity can quickly be elevated to the more important CAMELS component, as it is critical to the continued solvency of a distress financial institution. A bank may have good asset quality, strong earnings, and adequate capital, but if it is unable to maintain sufficient liquidity, it runs the risk of failure. (Hadley and Touhey 2007: 4)

This is precisely what happened to several big financial institutions in the recent financial crisis because of the cash-flow structure of their liabilities relative to the cash-flow structure of their assets even though they had adequate capital (Tymoigne 2009c).

Figure 2 shows that the same applied to the household sector recently. The wealth of households grew at rate superior to $10 \%$ on an annualized basis from the third quarter of 2003 to the second quarter of 2006 before recording historical drops from the first quarter of 2008. 
Figure 2. Net Worth of Households

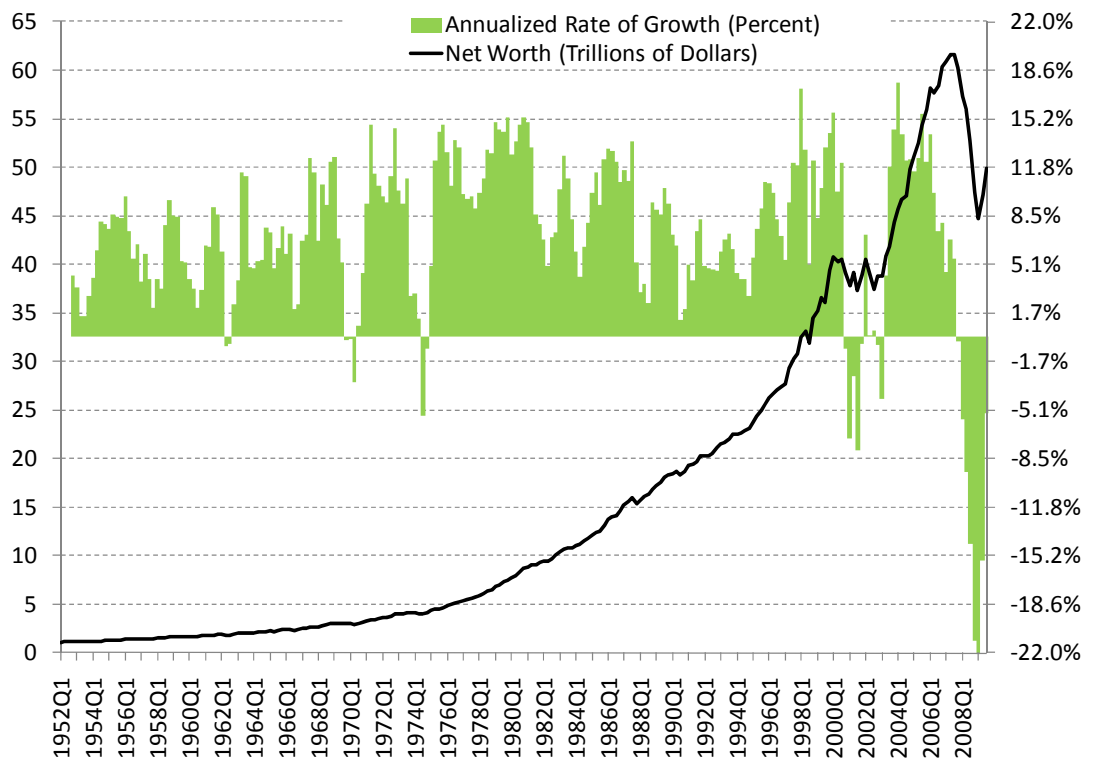

Source: Federal Reserve Board (Flow of Funds L.100, L.100.a)

As shown below, Ponzi finance was going on from around 2003, but this was masked by rapidly rising home prices:

Fitch believes that much of the poor underwriting and fraud associated with the increases in affordability products was masked by the ability of the borrower to refinance or quickly re-sell the property prior to the loan defaulting, due to rapidly rising home prices. (Pendley, Costello, and Kelsh 2007: 1)

Note, however, that this is not the first time such a sustained rapid growth of net worth has been recorded in the household sector. The end of the 1970s and the end of 1990s recorded an annualized growth rate of about $11.8 \%$ that was sustained for several quarters. The end of the $1990 \mathrm{~s}$ was followed by a rapid drop of wealth (a historical record at that time) following the stock market crashes. The 1970s did not record any drop in wealth, which means that the growth of wealth was based on a stronger footing. This tells us that not all high growth rates of net worth are signs of upcoming problems, something else has to happen in conjunction.

Third, even though net worth is expected to go down, Ponzi finance does not mean that an economic unit is insolvent, i.e., will never be able to meet its debt commitments. There are two reasons for this. First, if the overall balance sheet of an economic unit involves the expected use of Ponzi finance, net worth must be expected to be positive or at least only temporarily negative, 
otherwise honest ${ }^{2}$ bankers would never consent to satisfy the expected needs for refinancing and honest asset owners have no point in practicing Ponzi finance (Minsky 1980: 28). Thus, while in the near term it is expected that refinancing sources are needed to be able to meet cash commitments (and so avoid insolvency), it is expected that sometime in the future refinancing will no longer be needed and that an economic unit will be able to pay cash commitments on its own so that, overall, the lending operation is profitable for the banker and the borrower. Second, Ponzi finance does not need to concern the overall balance sheet of an economic unit, but may be localized in specific economic activities. Thus, the overall balance sheet of an economic unit may not have declining net worth or growing refinancing needs even though specific economic activities are Ponzi-financed. However, the greater the use of Ponzi finance, the lower the quality of leverage and so the greater the chance that, when refinancing channels close, a large decline in net worth will be recorded that may put an economic unit into insolvency. This state of insolvency, however, is not a signal of fragility, but a consequence of fragility.

Finally, Ponzi finance is also different from fraudulent and abnormal liability practices because some individuals may enter Ponzi processes while playing by the rules of law and while following the financial norms of behaviors established by society. Thus, everybody may behave "wisely" or "properly," but still may contribute a great deal to a rising financial fragility. It is a well-known central point of Minsky's approach that lending norms loosen over time and that what was previously considered a too risky funding method may become commonly accepted. This change in norms, however, does not make Ponzi finance harder to detect because it is defined independently of those norms as explained above. All this is important for empirical purposes because the point of detecting financial fragility is not to detect "dishonest, incompetent, and inequitable elements of banking" or of other economic sectors. Thus, the purpose is also different from the traditional approach of bank supervision and early warning systems that implicitly assumes that fraud and/or bad management are at the core of all the problems of economic units, and so use declining profitability, rising default, and other measures of economic troubles to measure financial fragility. As noted several times before, if one conceives financial fragility via Ponzi finance, one

\footnotetext{
2 The honesty of the bankers (and borrowers) is actually extremely important for this point. As Black (2005) and Akerlof and Romer (1993) have demonstrated, the logic of crooks is very different from that of honest bankers because negative net worth is not a deterrent for fraudulent bankers. Indeed in this case, the point becomes to grow rapidly by granting very bad loans (preferably non-recourse), charging very high interest rates, and putting staff on remuneration schemes based on loan volume rather than loan quality. This is sure to lead to a catastrophe for the bank (and the economy), but it will make some of the crooks very rich. In addition, in case fraud is present, accounting tricks will be used and will create difficulties detecting Ponzi finance (Minsky 1989: 180).
} 
must first concentrate on the finance of economic units, and rising net worth and declining default rates are not a sign of lower financial fragility. Of course, fraudulent activities usually involve some forms of Ponzi finance so the two purposes are not exclusive, but the purpose of detecting financial fragility is broader than the purpose of detecting fraud, and so involves broader supervisory and regulatory implications (Tymoigne 2009c).

\section{A SUGGESTED APPROACH FOR DETECTING PONZI FINANCE WITH AN APPLICATION TO HOUSEHOLD MORTGAGE FINANCE}

Now that the ground has been set up for the methodology used in this paper and how it compares to other studies, the following proposes a measure of Ponzi finance. Following the methodology set up above, the paper endeavors to look at specific activities within the balance sheet of each economic sector and to study the way they are financed and funded. This paper illustrates the method by looking at the way residential housing has been funded by households.

\subsection{Some Data}

In terms of cash flow, we know that a central aspect of Ponzi finance is that net cash flows from operation are expected to be too low to meet debt commitments. For households, the net cash flow from operation is their disposable labor and financial earnings less living expenses necessary to maintain their currency standard of living:

$N C F_{O}=Y_{W}+Y_{F}-T-C O_{C}$

With $Y$ the amount cash flow induced by labor earnings $\left(Y_{W}\right)$ and by financial gains $\left(Y_{F}\right), T$ taxes paid by households (net of subsidies), and $\mathrm{CO}_{C}$ the cash outflow induced by consumption of goods and services that can be smaller than consumption. Note that, ideally, cash inflows from financial gains should exclude any exceptional financial gains like, for example, capital gains induced by defensive liquidation because the latter is part of position-making operations. Similarly, exceptional labor earnings, like one-time unexpected bonus, should be excluded. The goal is ideally to get an idea of the capacity of households to meet their financial obligations from routine cashflow sources. This should then be compared to the cash outflows induced by financial obligations (mortgages, consumer debts, and others). Ideally, all this should be done in terms of expectations. 
Finally, if household income is used as a proxy for net cash inflows, the former should exclude all forms of imputed income and nonmonetary incomes so that only incomes that generate an increase in monetary assets are counted. For example, the NIPA income definition includes components such as the rental value of owner-occupied housing, employer contributions to private pension funds, and the value of Medicare and Medicaid entitlements. Other forms of income that are not appropriate to include are stock options and nonmonetary benefits from work.

Data about cash-flow ratios do exist for households. The Federal Reserve Board publishes quarterly data that is shown in figure 3 and the ratios divide cash commitments by after-tax income (which excludes the NIPA components described above [Dynan, Johnson, and Pence 2003: 423]). The relevant ratio for the measurement of financial fragility depends on the focus of the analysis. For our purpose, the mortgage financial obligation ratio is the most appropriate.

\section{Figure 3. Financial Obligation Ratio and Debt-service Ratio}

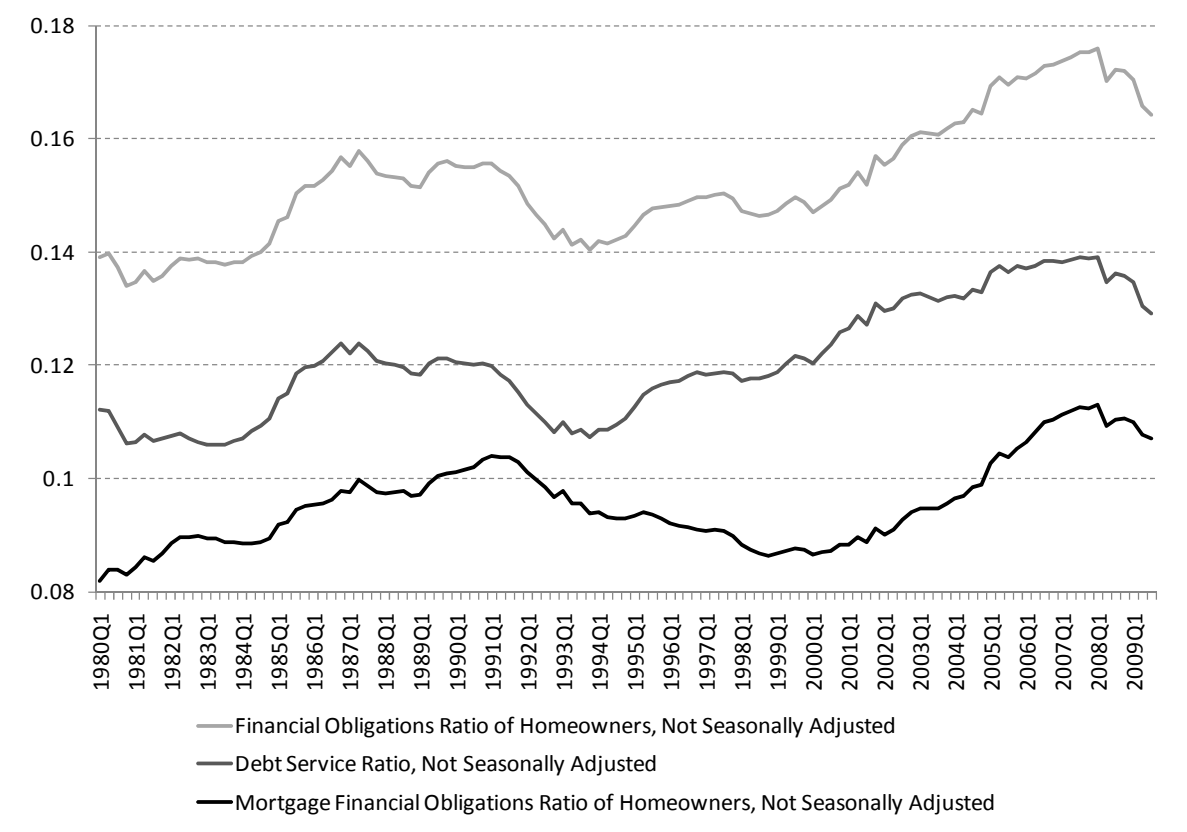

Source: Federal Reserve Board

Note: The mortgage financial obligation ratio of homeowners includes payments on mortgage debts, homeowners' insurance, and property taxes. The debt-service ratio only includes interest and principal payments on outstanding debts. The financial obligation ratio adds automobile lease payments, rental payments on tenant-occupied property, homeowners' insurance, and property tax payments to the debt-service ratio.

The striking feature of this data is that households, as a whole, never seem to engage in Ponzi finance because the cash-flow condition is never verified, i.e., none of the ratio is ever greater 
than one. What this tells us is that the aggregate cash-flow ratios can only be used as a first indicator of potential financial fragility and must be complemented by other macroeconomic and microeconomic data. In addition, there are several limitations to the ratios for our purpose (Dynan, Johnson, and Pence 2003).

First, it is a measure of actual cash-flow ratio rather than a measure of expected cash-flow ratio. As a consequence, financial fragility will be captured with a delay and the ratio does not capture the motivation behind the growth of cash commitments:

Some households may increase their ratios by borrowing more because they are appropriately optimistic about their future income prospects and their corresponding ability to repay debt. Other households may increase their ratios because they have suffered an unanticipated misfortune that necessitates borrowing to cover their extra expenses. An increase in the DSR [debt-service ratio] indicates good news for the economy in the first example and bad news in the second. (Dynan, Johnson, and Pence 2003: 417-418)

Second, the ratios are only a measure of the minimum financial burden on households, that is, they do not the measure the actual debt payments, but only the minimum payment households are required to make. Indeed, debt service is the sum of interest payments and principal payments. While relatively reliable data is available for interest payments, no such thing is available for principal payments; as a consequence, some approximations must be made about the average remaining maturity of some loans. Notably it is assumed that households only repay what they are required to repay, which on credit card debts is only $2.5 \%$ of the principal owed each month. Third, the debt-service ratio does not include all debts, but only the main debts. While consumer debts and mortgage debts represent over $90 \%$ of households' liabilities, as shown in figure 4 , troubles may come from leveraged speculation and other liabilities. At the same time, however, some of the debts included in the households sector by the flow of funds data are not paid by households (see note to figure 4), so, overall, the ratios probably capture most of the financial commitments of households. Fourth, to get a better sense of the financial fragility of households, the denominator should exclude cash outflow induced by consumption. Figure 5 shows the ratio of debt relative to net cash flow from operation for households. The overall picture is much bleaker than figure 4. Indeed, while the debt-to-disposable-income ratio doubled since the early 1980 s from $65 \%$ to $130 \%$, the debt-to-netoperating-cash-flow almost quintupled from about $500 \%$ to about $2,300 \%$. 


\section{Figure 4a. Financial Liabilities of Households relative to Disposable Personal Income}

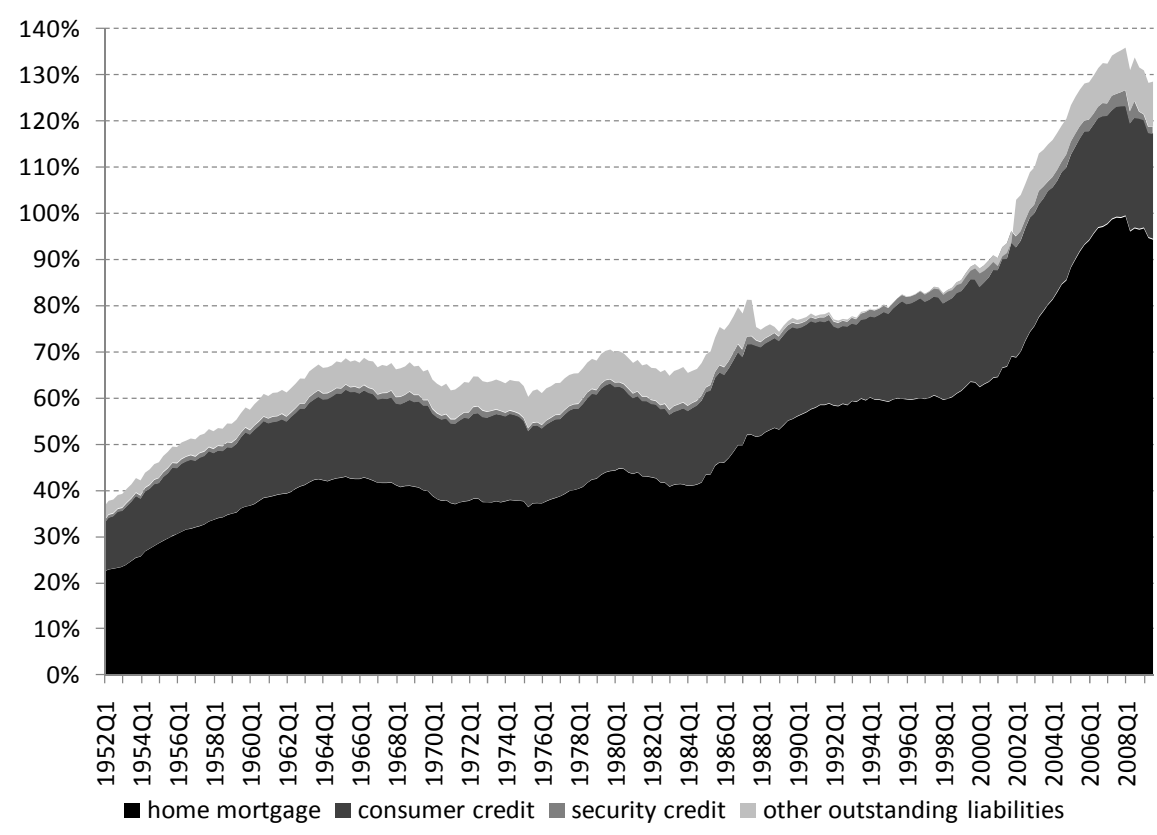

Sources: Federal Reserve Board (Flow of Funds, tables L.100 and L.100.a) and Bureau of Economic Analysis (NIPA, table 2.1).

Note: Other liabilities include loans extended by the Federal Reserve to financial institutions such as domestic hedge funds through the Term AssetBacked Securities Loan Facility (TALF), shown on table L.108, line 15. Home mortgage includes loans made under home equity lines of credit and home equity loans secured by junior liens, shown on table L.218, line 22. 
Figure 4b. Financial Liabilities of Households relative to Disposable Personal Income Excluding Income Imputations

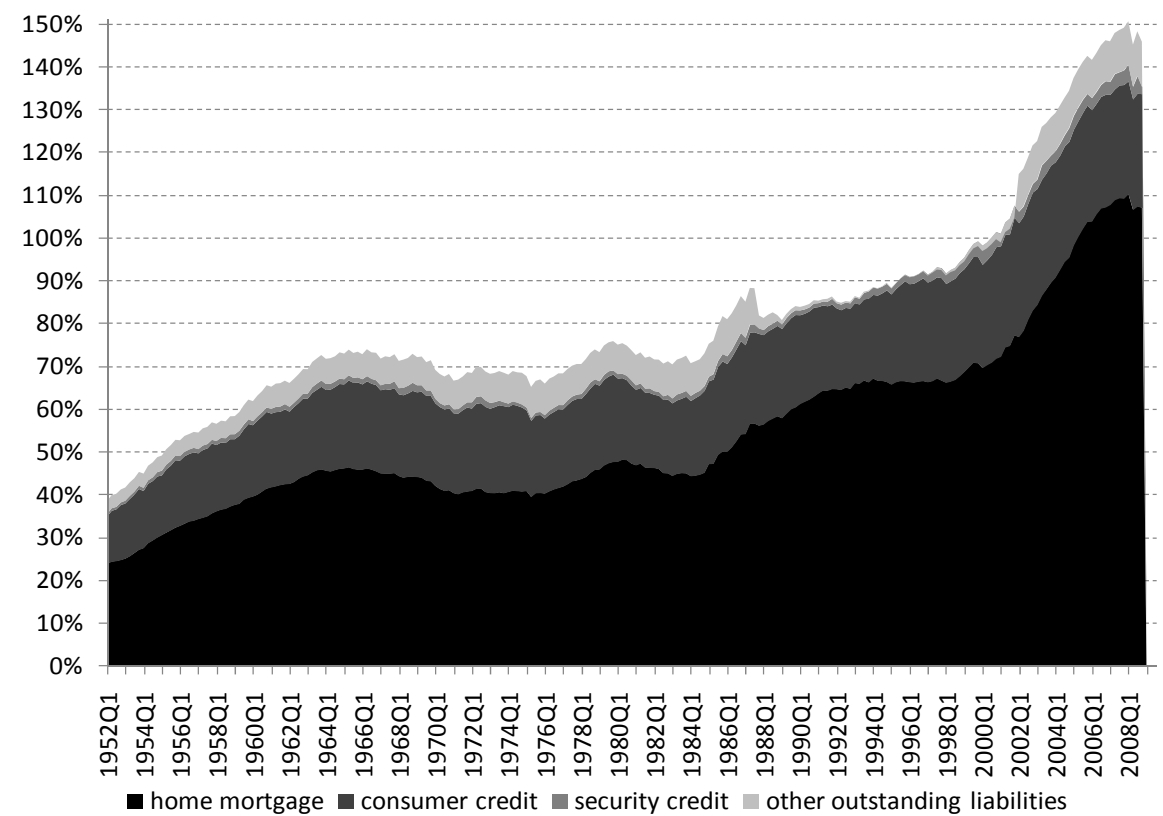

Sources: Federal Reserve Board (Flow of Funds, tables L.100 and L.100.a) and Bureau of Economic Analysis (NIPA, table 7.12).

Note: Imputations represent implicit monetary incomes received by households. They include, among others, farm products consumed on farm and implicit rental income of homeowners. 
Figure 5a. Financial Liabilities of Households relative to Net Cash Inflow after Taxes and Cash Outflow from Consumption

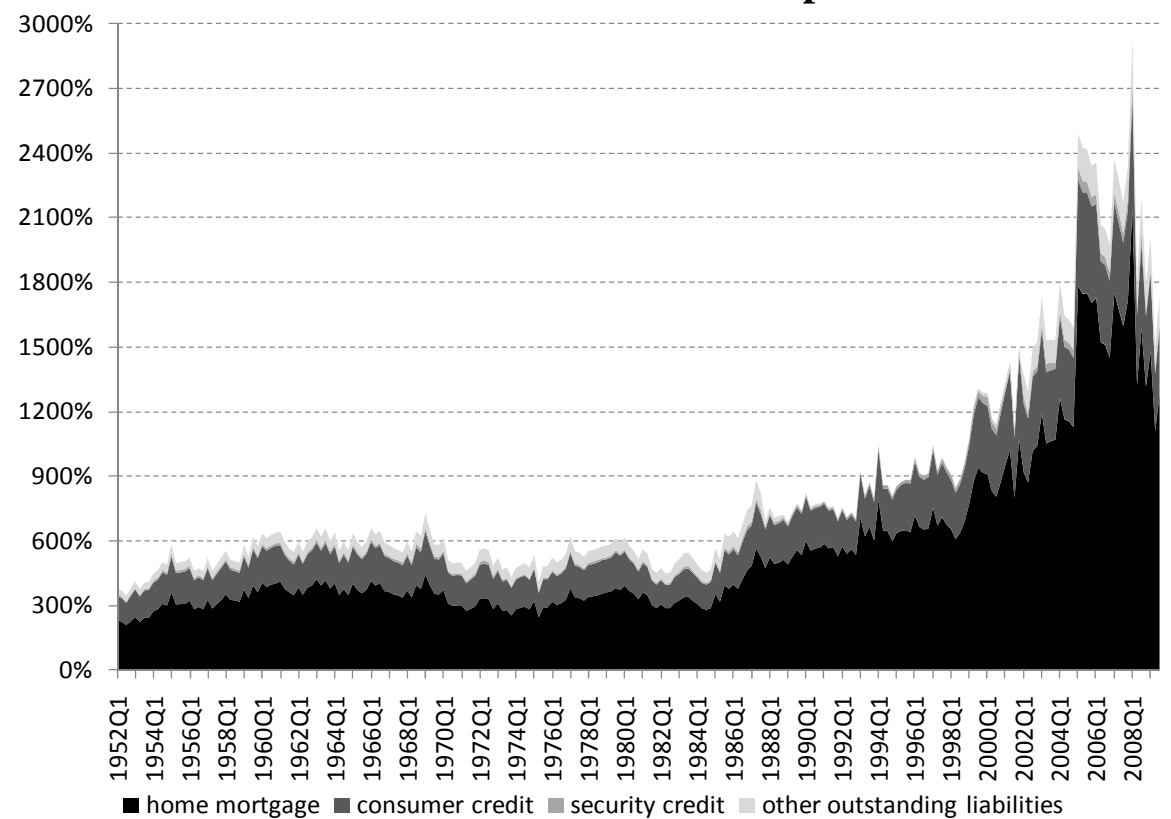

Sources: Federal Reserve Board (Flow of Funds, tables L.100 and L.100.a) and Bureau of Economic Analysis (NIPA, table 2.1).

Note: Net cash outflow from consumption is approximated by consumption less net change in consumer credit. 


\section{Figure 5b. Financial Liabilities of Households relative to}

Net Cash Inflow after Taxes excluding Imputed Income and Cash Outflow from Consumption Net of Imputed Consumption

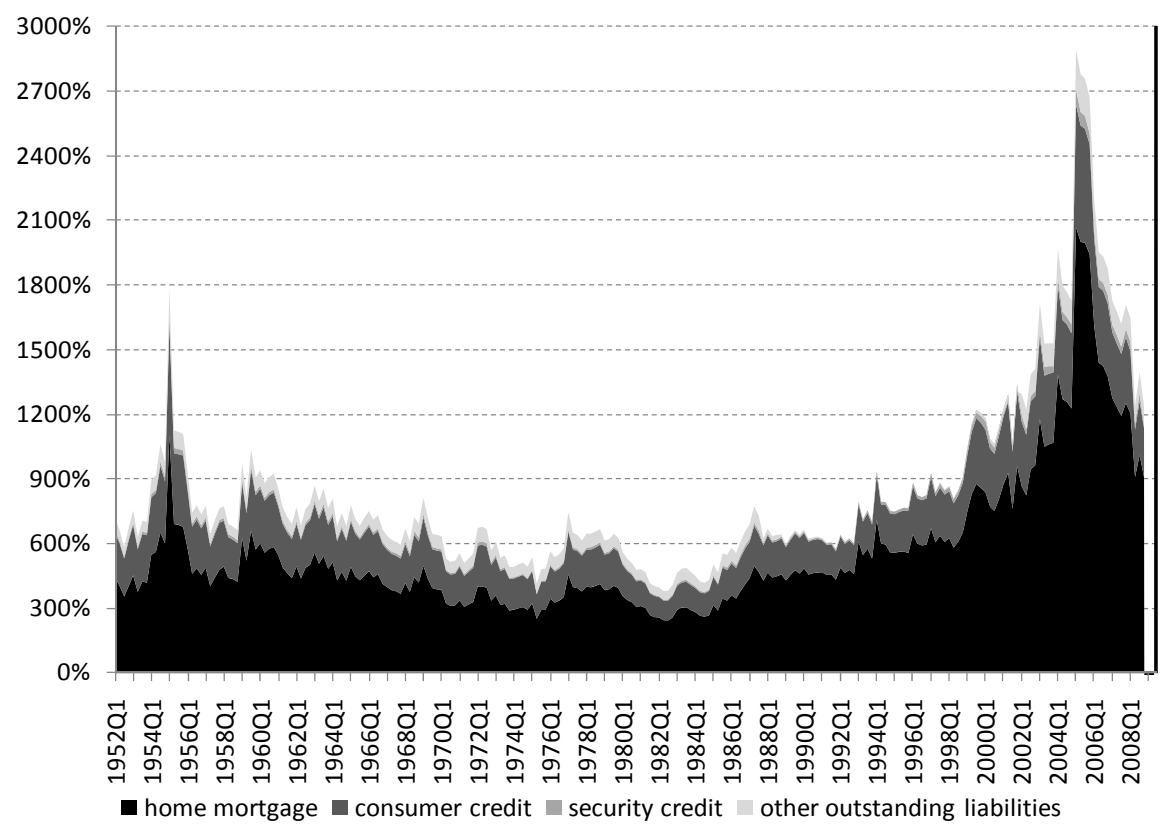

Sources: Federal Reserve Board (Flow of Funds, tables L.100 and L.100.a) and Bureau of Economic Analysis (NIPA, table 7.12).

Note: Net cash outflow from consumption is approximated by consumption net of imputed consumption less net change in consumer credit.

The limitations of cash-flow ratios imply that the data cannot be used directly to measure Ponzi finance. Instead a rising ratio will be of concern if it occurs simultaneously with other financial aspects. Indeed, given the cash-flow definition of Ponzi finance, two central features of Ponzi finance is that refinancing needs are growing and liquidity buffers are shrinking; therefore, a rising cash-flow ratio together with declining liquidity ratios and growing refinancing needs would provide a better indicator of Ponzi finance.

Regarding liquidity buffers, the amount of monetary assets (cash and deposits) and cash kickers (monetary assets and other very liquid assets) relative to the amount of debts has decreased dramatically over time. Thus, the capacity of households to respond to a situation where $N_{C F}<$ CC has decreased dramatically, especially since the end of the 1980s, creating a greater dependence on defensive position-making operations. 


\section{Figure 6. Liquid and Monetary Assets relative to Financial Liabilities}

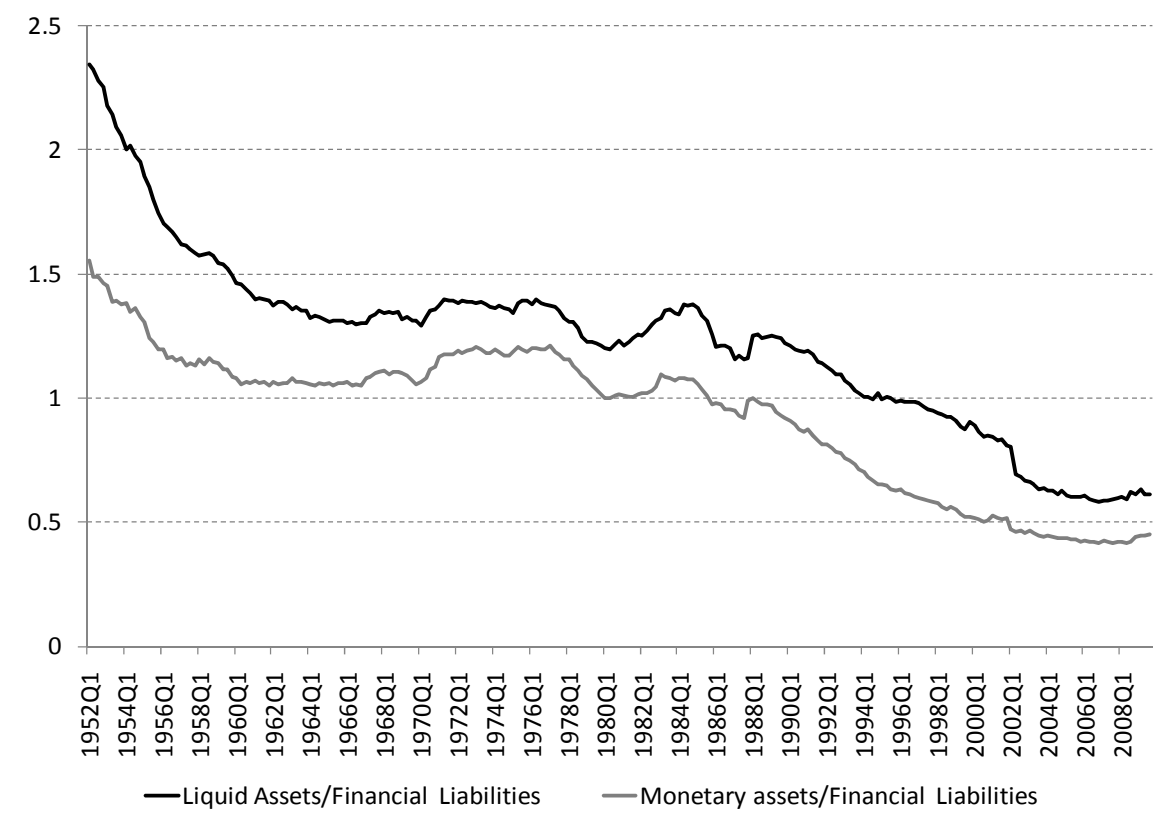

Source: Federal Reserve Board

Note: Monetary assets are composed of cash, demand deposits, and saving deposits. Liquid assets are composed of monetary assets, money-market mutual funds shares, foreign-currency holdings, and government and agency securities.

Regarding refinancing operations, partial datasets are available. For example, as shown in figures 7 and 8, Freddie Mac and the Federal Housing Finance Agency provide data about cash-out refinance and no-cash-out refinance (also called term-rate refinance). The former allows one to obtain funds to consolidate other debts or for other purposes. The latter allows mortgagees to refinance in order to obtain a mortgage with a lower mortgage services. Not surprisingly term-rate refinancing goes up when mortgage rates go down, while the cash-out refinancing goes up when home prices go up and confidence about the future is high. 
Figure 7. Percentage of Refinances Resulting in Cash-out Refinance with at least $5 \%$ Higher Loan Amounts

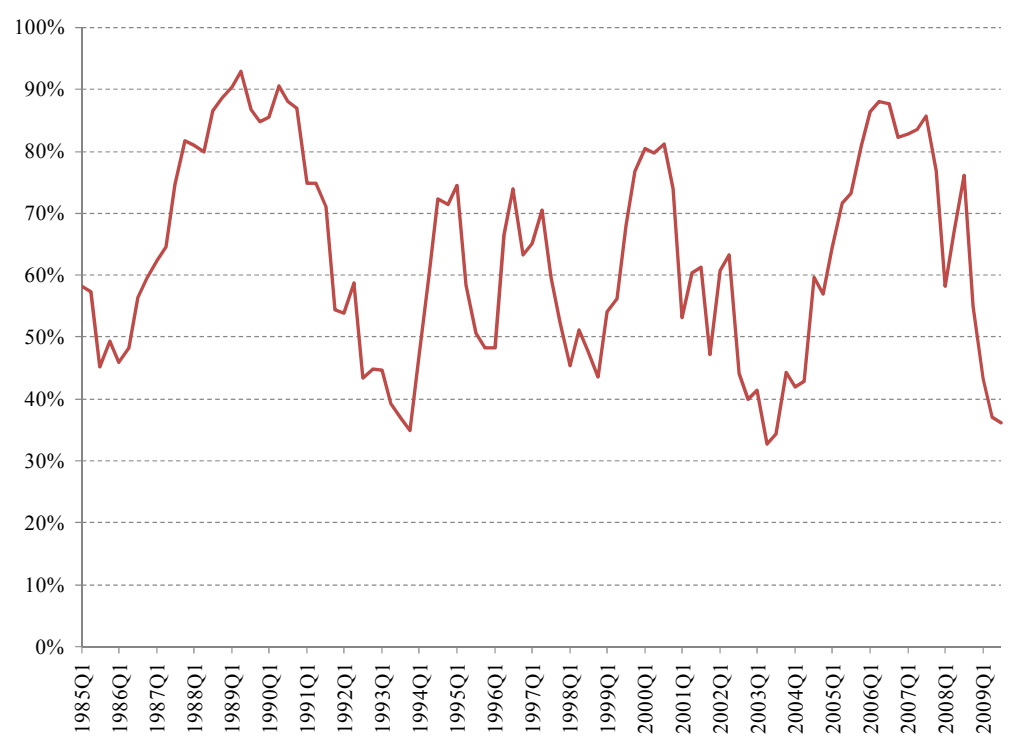

Source: Freddie Mac

Figure 8. Proportion of Cash-Out Refinance in Refinance Mortgages

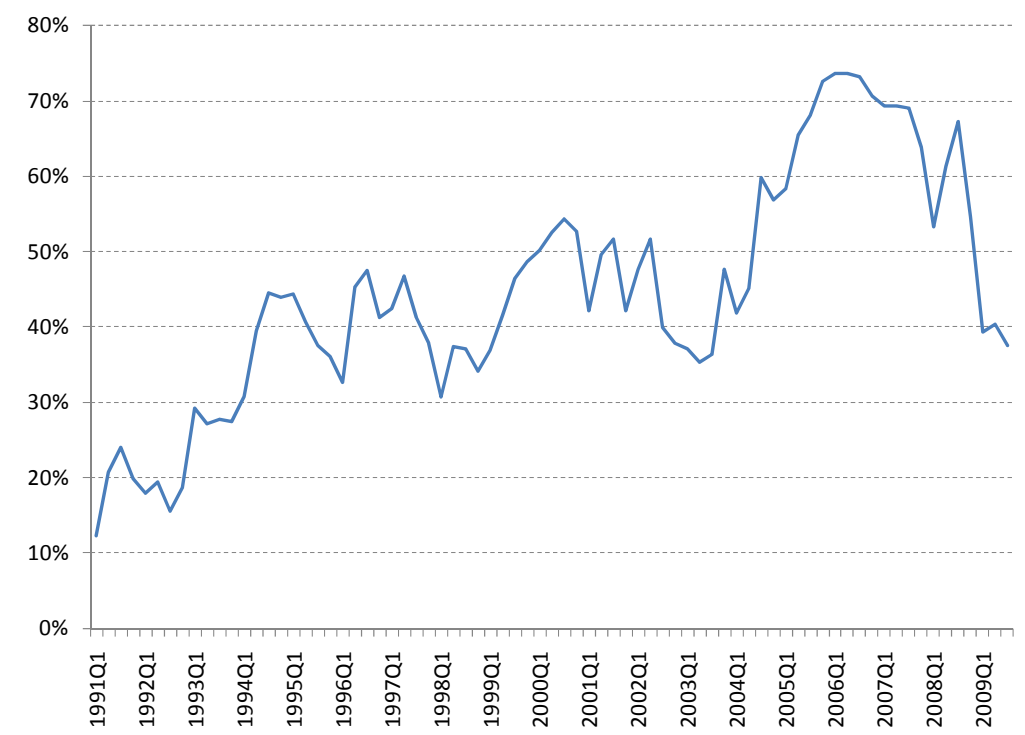

Source: Federal Housing Finance Agency

Note: Data for single-family detached properties financed by conforming conventional mortgages purchased by the Federal National Mortgage Association and the Federal Home Loan Mortgage Corporation. 
The data about refinancing are of limited scope because they relate exclusively to conforming conventional mortgages, which are overwhelmingly prime mortgages. This means that a good part of the Ponzi process going on in the 2000s cannot be captured through this data; however, even the prime mortgage business in the United States became based on Ponzi finance with a high reliance on low-doc mortgages and expectations that home prices would continue to rise (Tymoigne 2009b). For example, in 2006, about 35\% of prime mortgages were low-doc mortgages. An interesting data set to get would be the ratio of cash-out refinancing relative to all mortgages to really get an idea of refinancing pressures in housing finance.

\subsection{Ponzi Finance in Residential Housing}

The previous data can be used to develop an index of Ponzi finance for residential housing in the household sector. One should be aware of the limits of the data backing the index; given their limits, it is safe to say that the index underestimates financial fragility. All variables are transformed into four-quarter moving averages in order to smooth the data. We first start by a simple index that includes the growth of home prices $\left(g_{P}\right)$, the growth of mortgage debt $\left(g_{D}\right)$, and the growth of the mortgage financial obligation ratio $\left(g_{C C}\right)$. The index takes a value of one if all the variables are positive and takes a value of zero otherwise:

\section{$I=\left.\right|_{0} ^{1}$ if $g_{D}>0, \varepsilon_{D}>0$, and $\varepsilon_{C E}>0$}

The result is shown in figure 9. The index finds two relevant periods of Ponzi finance in the household sector, one from 1989 to 1990 and one from the end of 1999 to early 2007, after which the moving average of home prices declined. 


\section{Figure 9. Index 1 of Ponzi Finance}

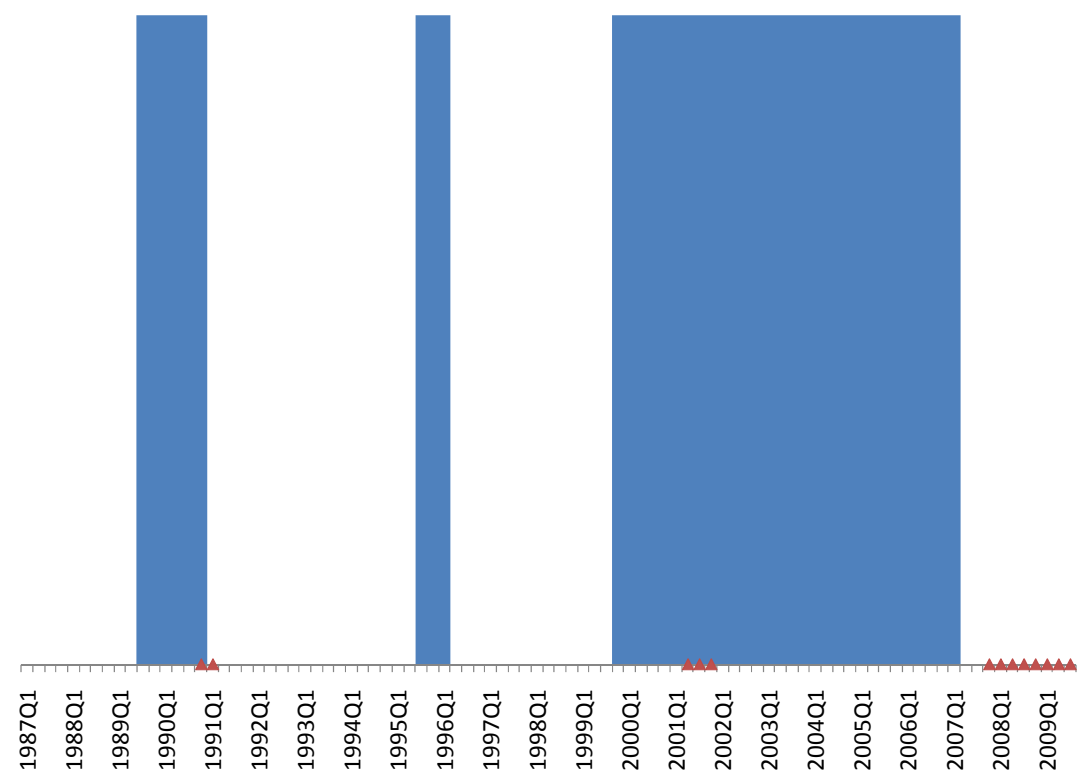

Sources: Flow of Funds, NBER, calculations by author.

Note: Triangles are for contraction phases.

Note that the 2001 recession does not seem to have any impact on the financial dynamics of the residential housing. We know that home equity loans started to rise significantly from the end of the 1990s, so much so that some FOMC members began to notice a potential problem:

There are people making real estate investments for residential and other purposes in the expectation that prices can only go up and go up at accelerating rates. Those expectations ultimately become destabilizing to the economic system. (Jordan, FOMC Transcripts, February 1999: 123)

A second index includes all the previous variables and adds the growth of the ratio of monetary assets to mortgage debts $\left(g_{M / D}\right)$. The index works as followed:

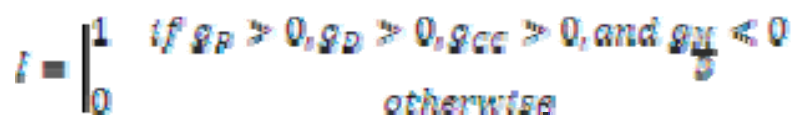

Note that the variables must all simultaneously behave in the previous way for the index to get a value of 1 . As long as one of the growth conditions is not met the index takes a value of 0 . 
Figure 10. Index 2 of Ponzi Finance with Monetary Asset Restriction

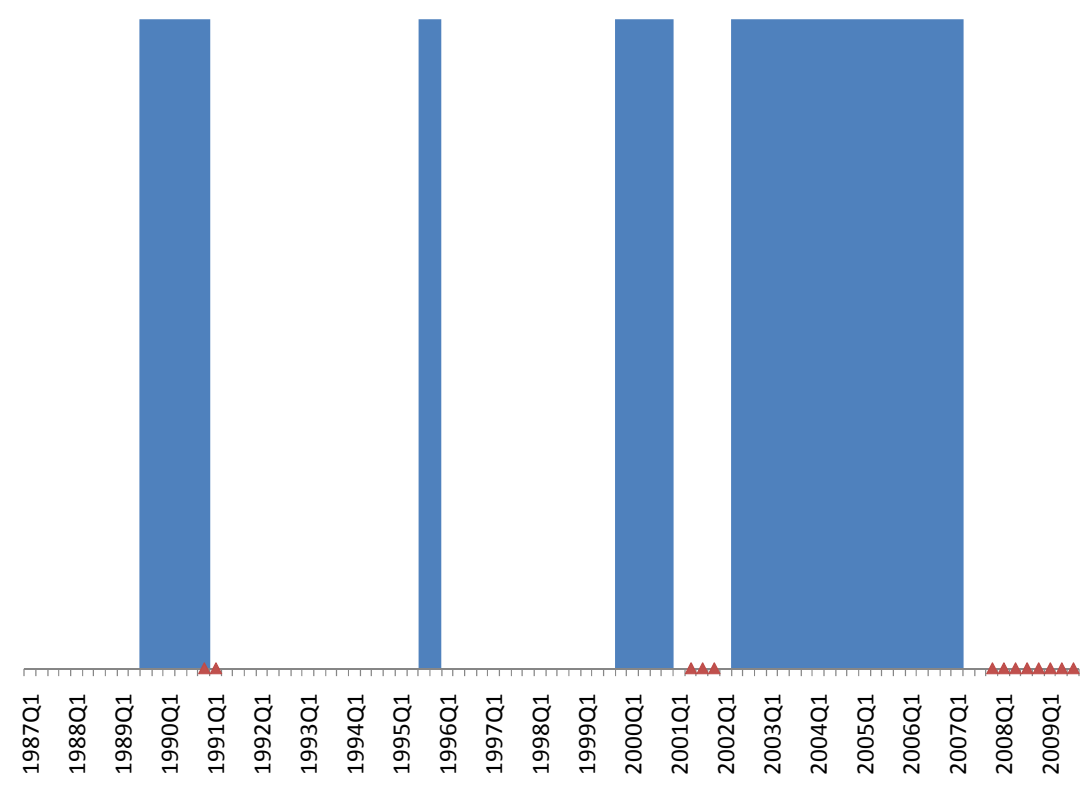

Sources: Flow of Funds, NBER; calculations by author

Note: Triangles are for contraction phases.

The index provides similar results except that the recession creates a break in the Ponzi process within home finance. A third index adds the effect of refinancing operations into the index. In this case, the index uses data about cash-out refinance that are provided in figure 7. I would have preferred to use the data of figure 8, but the dataset is too short. However, a test of the index over the period 1991-2009 with the proportion of cash-out refinance leads to the same period of Ponzi finance. Figure 11 shows the index. 


\section{Figure 11. Index of Ponzi Finance with Monetary Asset and Refinancing Restrictions}

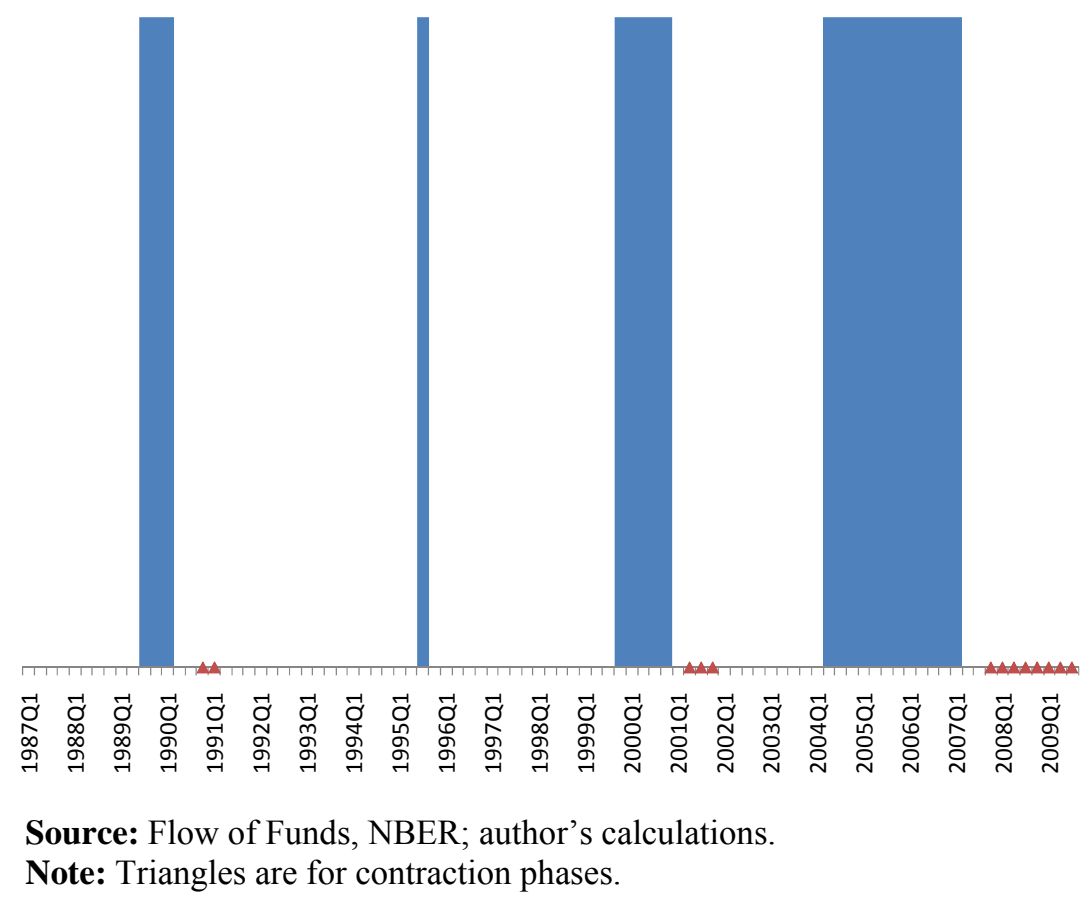

The index takes a value of 1 if home prices are rising, mortgage debt is rising, the mortgage financial obligation is rising, and cash-out refinancing leading to a new outstanding mortgage at least 5\% bigger than the previous mortgage is rising. Given that it is the most restrictive all of the three indexes (especially given the scope of refinancing data), the period of Ponzi finance is now smaller for the 1980s and for the 2000s. The most recent period recorded the use of Ponzi finance in housing from the second quarter of 2004 to the first quarter of 2007, after which the moving average of home prices started to decline.

Overall those indicators do seem to capture some important aspects of financial fragility among households' residential housing activities. Each period, 1989-1990, 1999-2000, and 20032007, was a period during which we know that housing finance was based on unsustainable financial practices. These three periods detected by the indexes are, however, of limited range. The housing boom in the United States started much earlier in the 1980s and slightly earlier in the 2000s when, by 2002 at least some data suggest that Ponzi finance was already going on, even in prime mortgage lending (Tymoigne 2009b). The limited scope of the data helps to explain why the last index detects smaller periods of financial fragility.

Beyond housing finance, we also know that consumer finance has been heavily sustained by debt. In fact, we know that most of the 1990s were driven by a stock market boom that fueled 
consumer debt so probably consumption would be a better candidate for Ponzi financing in the 1990s.

\section{CONCLUSION}

Different frameworks of analysis lead to different conceptions of financial instability and financial fragility. On one side, the static approach conceptualizes financial instability as an unfortunate byproduct of capitalism that results from unpredictable random forces that no one can do anything about except prepare for through adequate loss reserves, and capital and liquidation buffers. On the other side, the evolutionary approach conceptualizes financial instability as something that the current economic system invariably brings upon itself through internal market and nonmarket forces and that requires change in financial practices rather than merely good buffers. This paper rapidly compares the two approaches in order to lay the foundation for the empirical analysis developed within the evolutionary approach. The paper shows that, with the use of macroeconomic data, it is possible to detect financial fragility, especially Ponzi finance. The methodology is applied to residential housing in the U.S. household sector and was able to capture some of the trends that are known to be sources of economic difficulties. Notably the paper finds that Ponzi finance was going on in homeownership from at least 2004 to 2007, which concurs with other works based on more detailed data.

Note that these results not only tell us something about household finance, but they also tell us something about the underwriting strategies of the banking sector. Thus, one does not need to carefully study the banking sector to know that financial fragility is developing in the latter. One may look at the finances of other sectors and what they are allowed to do in order to discover that unsustainable financial practices are going on in the banking sector, which may warrant further analysis. This is important because the banking sector is probably the most complex sector to analyze in terms of finances, given the heavy reliance on securitization and off-balance sheet accounting.

In addition, this paper has some important implications for regulatory reform. It shows, for example, that the quality of leverage, rather than its quantity, plays a central role in the growth of financial fragility, and that the quality of the leverage is unrelated to capital equity or profitability. A highly profitable business with a strong capital base and a rapidly rising net worth may hide unsustainable funding practices that generate financial instability. For example, the paper showed 
that the rapidly rising net worth of households in the 2000s was not sustainable. At the time, however, the growing net worth of households was used to justify the rapid growth of debt. The paper, however, argues that this is an unwarranted justification because households do not use their home of residence to pay their mortgage and other debts, they use their income and cash hoards. Thus, unless households' income rises sufficiently, it is does not make sense to let households "use their home equity" to borrow.

More broadly, the paper argues that collateral does not pay for anything. Ultimately only cash hoards and cash flows from normal economic operations do so and collateral-based lending promotes financial instability. While authors of the static approach state that providing more collateral eliminates Ponzi finance, the evolutionary approach actually shows that more collateral puts oil on the fire because Ponzi finance involves collateral-based lending and so more collateral feeds the process. Thus, in order to stop Ponzi finance and to promote financial stability, we need a return to sound underwriting practices based on income. Greater collateral availability should not justify greater lending — greater income should — and collateral should be put back into its proper place in the underwriting process, which is to provide a guarantee to the lender against incapacity to pay. That should be a central agenda of reform rather than the definition of a specific capital adequacy ratio and liquidity buffers. Indeed, while having appropriate buffers against expected and unexpected losses and liquidity needs is important, focusing the discussion purely on those issues not only forgets about how the economic system ends up needing those buffers, but also ignores the fact that Ponzi finance can wipe out any buffer very rapidly even if they are well above required buffers.

This paper has only scratched the surface in terms empirical analysis, similar work can be done to check the status of consumer finance and of investment finance in different industries. This is the next stage of the analysis. 


\section{APPENDIX 1: THE CASH-FLOW GROWTH CONDITION FOR PONZI FINANCE}

We know that Ponzi finance involves:

$Y<(a+i) L$

with $Y$ the nominal level of "income" (more precisely, net cash inflow from core economic operations) and $(a+i) L$ the nominal level of debt services. A necessary, but not sufficient, condition for this to occur is that the growth rate of income be lower than the growth rate of debt-service payments. If we note $S$ the nominal level of debt-service payment, we have:

$g_{Y}<g_{S}$

The growth rate of debt service is found by taking the derivative of logarithm of the debt service $S$ :

$\log (S)=\log (a+i)+\log L$

thus:

$\frac{d S}{S}=\frac{d(a+D)}{(a+i)}+\frac{d L}{L}$

Given that $d$ is a linear operator we have:

$\frac{d S}{S}<\frac{d a}{(a+i)}+\frac{d i}{(a+i)}+\frac{d L}{L}$

Thus:

$\frac{d S}{S}=\frac{d a}{a} \cdot \frac{a L}{(a+b) L}+\frac{d t}{t} \cdot \frac{b L}{(a+b)}+\frac{d L}{L}$ 
$d X / X$ is the growth rate of variable $X$, noted $g_{X}$, and $a L /(a+i) L$ is the share of capital component of debt service, noted $s_{A}$. Thus, for asymptotic variations we have:

$g_{Y}<g_{a} s_{A}+g_{i} s_{I}+g_{L}$

For discrete variations $\left(g_{X}=\Delta X / X\right)$, the condition is different and is found by starting with the growth of debt service $(S=(a+i) L)$ :

$S\left(1+g_{S}\right)=\left(i\left(1+g_{i}\right)+a\left(1+g_{a}\right)\right) L\left(1+g_{L}\right)$

Thus, given that $L / S=(i+a)$ :

$1+g_{S}=\left[\frac{i}{(a+i)}\left(1+g_{i}\right)+\frac{a}{(a+i)}\left(1+g_{a}\right)\right]\left(1+g_{L}\right)$

We know how shares are defined, so the discrete growth rate of debt service is:

$g_{S}=\left[\left(1+g_{a}\right) s_{A}+\left(1+g_{i}\right) s_{I}\right]\left(1+g_{L}\right)-1$

Thus, the discrete Ponzi condition in terms of growth rate is:

$g_{Y}<\left[\left(1+g_{a}\right) s_{A}+\left(1+g_{i}\right) s_{I}\right]\left(1+g_{L}\right)-1$ 


\section{REFERENCES}

Akerlof, G.A., and P.M. Romer. 1993. "Looting: The economic underworld of bankruptcy for profit.” Brookings Papers on Economic Activity 1993(2): 1-60.

Araujo, A., M.R. Páscoa, and J.P. Torres-Martínez. 2002. “Collateral avoids Ponzi schemes in incomplete markets.” Econometrica 70(4): 1613-1638.

Aspachs, O., C.A.E. Goodhart, D.P. Tsomocos, and L. Zicchino. 2007. "Towards a measure of financial fragility." Annals of Finance 3(Special Issue): 37-74.

Bårdsen, G., K.-G. Lindquist, and D. P. Tsomocos. 2006. "Evaluation of macroeconomic models for financial stability analysis." Norwegian University of Science and Technology, Department of Economics, Working Paper Series No. 4/2006.

Bell, J. 2000. "Leading indicator models of banking crises: A critical review." Bank of England Financial Stability Report, December: 113-129.

Berg, A., E. Borensztein, and C. Pattillo. 2004. “Assessing early warning systems: How have they worked in practice?" International Monetary Fund, Working Paper WP/04/52.

Bernanke, B.S., and M. Gertler. 1990. "Financial fragility and economic performance.” Quarterly Journal of Economics 105(1): 87-114.

Black, W.K. 2005. The Best Way to Rob a Bank Is to Own One: How Corporate Executives and Politicians Looted the S\&L Industry. Austin: University of Texas Press.

Bordo, M., B. Eichengreen, D. Klingebiel, and M. Martinez-Peria. 2001. "Is the Crisis Problem Growing more Severe?” Economic Policy 16(32): 51-82.

Bussiere, M., and M. Fratzcher. 2002. "Toward a new early warning system of financial crises." European Central Bank, Working Paper No. 145.

Cecchetti, S.G., M. Kohler, and C. Upper. 2009. "Financial Crises and Economic Activity." Mimeograph.

Davis, E.P. 1995. Debt, Financial Fragility, and Systemic Risk, 2nd edn. Oxford: Oxford University Press.

Davis, E.P., and M.R. Stone. 2004. "Corporate financial structure and financial stability." International Monetary Fund, Working Paper No. 04/124.

De Bondt, W.F.M., and R.H. Thaler. 1985. "Does the stock market overreact?" Journal of Finance 40(3): 794-805. 
. 1995. "Financial decision-making in markets and firms: A behavioral perspective." in R. Jarrow, V. Maksimovil, and W.T. Ziemba (eds.), Handbook in Operations Research and Management Science, vol. 9. San Diego: Elsevier.

De Paula, L.F.R., and A.J. Alves, Jr. 2000. "External financial fragility and the 1998-1999 Brazilian currency crisis.” Journal of Post Keynesian Economics 22(4): 589-617.

Demirgüç-Kunt, A., and E. Detragiache. 1998. "The determinants of banking crises in developing and developed countries." IMF Staff Papers 45(1): 81-109.

Domar, E.D. 1944. "The 'burden of the debt' and the national income." American Economic Review 34(4): 798-827.

Dr. Housing Bubble. 2009. "The truth about option arms, pick-a-pay mortgages, and alt-a loans: Looking at Wells Fargo, Bank of America, and JP Morgan.” Accessed March 26, 2010 at http://www.doctorhousingbubble.com/the-truth-about-option-arms-pick-a-pay-mortgagesand-alt-a-loans-looking-at-wells-fargo-bank-of-america-and-jp-morgan-we-are-in-the-eyeof-the-469-billion-toxic-mortgage-hurricane-and-silence/

Dynan, K., K. Johnson, and K. Pence. 2003. "Recent Changes to a Measure of U.S. Household Debt Service.” Federal Reserve Bulletin, October: 417-426.

Edison, H.J. 2000. "Do indicators of financial crises work? An evaluation of an early warning system.” Board of Governors of the Federal Reserve System, International Financial Discussion Paper No. 675.

Estenson, P.S. 1987. "Farm debt and financial instability." Journal of Economic Issues 21(2): 617627.

Fell, J., and G. Shinasi. 2005. "Assessing financial stability: Exploring the boundaries of analysis." National Institute Economic Review 192: 102-116.

Foley, D.K. 2003. "Financial fragility in developing countries." in A. Dutt and J. Ros (eds.), Development Economics and Structuralist Macroeconomics: Essays in Honour of Lance Taylor. Cheltenham, UK: Edward Elgar.

Galbraith, J.K. 1961. The Great Crash, 3rd edn. Cambridge, MA: The Riverside Press.

Gaytàn, A., and C.A. Johnson. 2002. "A review of the literature on early warning systems for banking crises." Central Bank of Chile, Working Paper No. 183.

Gertler, M. 1988. "Financial structure and aggregate economic activity: An overview." Journal of Money, Credit and Banking 20(3), Part 2: 559-588.

Goldstein, M., G. Kaminsky, and C. Reinhart. 2000. Assessing Financial Vulnerability: An Early Warning System for Emerging Markets. Washington, D.C.: Peterson Institute for International Economics. 
Goodhart, C.A.E., P. Sunirand, and D.P. Tsomocos. 2006. "A Time Series Analysis of Financial Fragility in the UK Banking System.” Annals of Finance 2(1): 1-21.

Gonzalez-Hermosillo, B. 1999. "Developing indicators to provide early warnings of banking crises.” Finance \& Development June: 36-42.

Grabel, I. 2003. "Predicting financial crisis in developing economy: Astronomy or astrology." Eastern Economic Journal 29(2): 243-258.

Greenspan, A. 2004. "The mortgage market and consumer debt." Remarks by Chairman Alan Greenspan at America's Community Bankers Annual Convention, Washington, D.C., October 19. Accessed April 52010 at:

http://www.federalreserve.gov/boarddocs/speeches/2004/20041019/default.htm.

. 2005. "Federal Reserve Board's Semiannual Monetary Policy Report to the Congress Before the Committee on Financial Services.” U.S. House of Representatives, July 20. Accessed April 4, 2010 at:

http://www.federalreserve.gov/boarddocs/hh/2005/july/testimony.htm.

Guttentag, J., and R. Herring. 1984. "Credit rationing and financial disorder.” Journal of Finance 39(5): 1359-1382.

Hadley, K.L., and A.T. Touhey. 2006. “An assessment of traditional liquidity ratios.” FDIC Outlook, Fall: 11-16. . 2007. "Liquidity analysis: Decades of change.” FDIC Supervisory Insights 4(2): 4-11.

Hardy, D.C. 1998. “Are banking crises predictable?” Finance \& Development, December: 32-35.

Hume, M.J., and A. Sentence. 2009. "The global credit boom: Challenges for macroeconomics and policy." Journal of International Money and Finance 28(8): 1426-1461.

Hu, H.T.C. 2008. "Credit default swaps and the financial crisis: 'Interconnectedness' and beyond." Hearing on The Role of Credit Derivatives in the U.S. Economy, U.S. House Committee on Agriculture, October 13. Accessed March 10, 2009 at: http://agriculture.house.gov/testimony/110/h81015/Hu.pdf.

Hu, H.T.C., and B.S. Black. 2008. "Equity and Debt Decoupling and Empty Voting II: Importance and Extensions." University of Pennsylvania Law Review 156(3): 625-739.

International Monetary Fund. 2007. "Financial market turbulence: Causes, consequences, and policies." Global Financial Stability Report, October. Washington, DC: International Monetary Fund.

. 2009. Global Financial Stability Report, April. Washington, D.C.: International Monetary Fund. 
Isenberg, D.L. 1988. "Is there a case for Minsky's financial fragility hypothesis in the 1920s?" Journal of Economic Issues 22(4): 1045-1069.

1994. "Financial fragility and the Great Depression: New evidence on credit growth in the 1920s." in G.A. Dymski and R. Pollin (eds.), New Perspectives in Monetary Macroeconomics: Explorations in the Tradition of Hyman P. Minsky. Ann Arbor: University of Michigan Press.

Kaminsky, G., and C. Reinhart. 1999. "The twin crises: The causes of banking and balance of payments problems.” American Economic Review 89(3): 473-500.

Kiyotaki, N., and J. Moore. 1997. “Credit Cycles.” Journal of Political Economy 105(2): 211-248.

Klein, L.R., and T. Shabbir. 2003. "Asia before and after the financial crisis of 1997-98: A retrospective essay." in L.R. Klein and T. Shabbir (eds.), Recent Financial Crises: Analysis, Challenges and Implications. Chetelman, UK: Edward Elgar.

Knutsen, S., and E. Lie. 2002. "Financial fragility, growth strategies and banking failures: The major Norwegian banks and the banking crisis, 1987-92." Business History 44(2): 88-111.

Kregel, J.A. 1997. "Margins of safety and weight of the argument in generating financial crisis." Journal of Economic Issues 31(2): 543-548.

. 1998. "Derivatives and global capital flows: applications to Asia." Cambridge Journal of Economics 22(6): 677-692.

. 2004. "Using Minsky to analyze the impact of international development finance on international financial stability." Center for Full Employment and Price Stability, Working Paper No. 33.

. 2008. "Minsky's cushions of safety systemic risk and the crisis in the U.S. subprime mortgage market." Public Policy Brief No. 93. Annandale-on-Hudson, NY: Levy Economics Institute of Bard College.

Lavoie, M., and M. Seccareccia. 2001. “Minsky’s financial fragility hypothesis: A missing macroeconomic link?" in R. Bellofiore and P. Ferri (eds.), Financial Fragility and Investment in the Capitalist Economy: The Economic Legacy of Hyman Minsky, vol. 2. Cheltenham, UK: Edward Elgar.

Levine, C., and T. Coburn. 2010. Exhibits for Hearing on Wall Street and the Financial Crisis: The Role of High Risk Home Loans, United States Senate, Permanent Subcommittee on Investigations, Committee on Homeland Security, and Governmental Affairs, April 13. Accessed April 10, 2010 at: http://hsgac.senate.gov/public/_files/Financial_Crisis/041310Exhibits.pdf.

Lestano, L. J. Jacobs, and G.H. Kuper. 2003. "Indicators of financial crises do work! An earlywarning system for six Asian countries." University of Groningen, CCSO Centre for Economic Research, Working Papers No. 200313. 
Marlor, A.F. 1997. "Macroeconomic indicators of systemic risk." Quarterly Review-Sveriges Riksbank 1: 17-30.

Mishkin, F.S. 1991. "Asymmetric information and financial crises: A historical perspective." in R. G. Hubbard (ed.), Financial Markets and Financial Crises. Chicago: University of Chicago Press.

Mishkin, F.S., and E.N. White. 2003. "Stock market bubbles: When does intervention work?" Milken Institute Review, 2nd quarter: 44-52.

Minsky, H.P. 1964. "Financial crisis, financial systems and the performance of the economy." in Commission on Money and Credit (ed.), Private Capital Markets. Englewood Cliffs, NJ: Prentice-Hall.

1972. "Financial instability revisited: The economics of disaster." in Board of Governors of the Federal Reserve System (ed.), Reappraisal of the Federal Reserve Discount Mechanism, vol. 3. Washington, DC: Board of Governors of the Federal Reserve System.

1975. "Suggestions for a cash flow-oriented bank examination." in Federal Reserve Bank of Chicago (ed.), Proceedings of a Conference on Bank Structure and Competition. Chicago: Federal Reserve Bank of Chicago.

. 1977. "Banking and a fragile financial environment." Journal of Portfolio Management, Summer: 16-22.

1980. "Finance and profit: The changing nature of American business cycles." in Joint Economic Committee (ed.), The Business Cycle and Public Policy, 1929-1980. Washington, DC: U.S. Government Printing Office; reprinted in H.P. Minsky (ed.) (1982) Can "It" Happen Again? Armonk: M.E. Sharpe.

. 1984. "Banking and industry between the two wars: The United States." Journal of European Economic History 13(Special Issue): 235-272.

1986. Stabilizing an Unstable Economy. New Haven, CT: Yale University Press.

1989. Comments on "Economic implications of the extraordinary movements in stock prices.” Brookings Papers on Economic Activity 1989(2): 173-182.

1995. "Financial factors in the economics of capitalism." Journal of Financial Services Research 9(3-4): 197-208; reprinted in H.A. Benink (ed.) (1995) Coping with Financial Fragility and Systemic Risk. Boston: Ernst and Young.

Niggle, C.J. 1989, “The cyclical behavior of corporate financial ratios and Minsky's financial instability hypothesis." in W. Semmler (ed.), Financial Dynamics and Business Cycles. New York: M.E. Sharpe.

Palley, T.I. 1994. "Debt, aggregate demand, and the business cycle: An analysis in the spirit of Kaldor and Minsky." Journal of Post Keynesian Economics 16(3): 371-390. 
Pendley, M.D., G. Costello, and M. Kelsh. 2007. "The Impact of Poor Underwriting Practices and Fraud in Subprime RMBS Performance.” FitchRating U.S. Residential Mortgage Special Report, November 28. Accessed April 15, 2010 at: http://www.securitization.net/pdf/Fitch/FraudReport_28Nov07.pdf.

Reinhart, C.M., and K.S. Rogoff. 2008. "Is the 2007 US sub-prime crisis so different? An international historical comparison.” American Economic Review 98(2): 339-344.

. 2009. "The aftermath of financial crises." American Economic Review 99(2): 466-472.

Rojas-Suarez, L. 2001. "Rating banks in emerging markets: What credit rating agencies should learn from financial indicators?" Peterson Institute for International Economics, Working Paper No. 01-6. Available at: http://www.iie.com/publications/wp/01-6.pdf.

Rose, A.K., and M.M. Spiegel. 2009. "Cross-country causes and consequences of the 2008 crisis: Early warning." Federal Reserve Bank of San Francisco, Working Paper No. 2009-17.

Schinasi, G.J. 2006. Safeguarding Financial Stability: Theory and Practice. Washington, DC: International Monetary Fund.

Schroeder, S.K. 2008. "The underpinnings of country risk assessment." Journal of Economic Surveys 22(3): 498-535.

- 2009. "Defining and detecting financial fragility: New Zealand's experience." International Journal of Social Economics 36(3): 287-307.

Schwartz, A.J. 1988. "Financial stability and the federal safety net." in W.S. Haraf and R.M. Kushmeider (eds.), Restructuring Banking and Financial Services in America. Washington, DC: American Enterprise Institute for Public Policy and Research.

. 1998. "Why financial stability depends on price stability." in G. Wood (ed.), Money, Prices and the Real Economy. Northampton, UK: Edward Elgar.

Schwartz, A.J. 1988. "Financial stability and the federal safety net." in W.S. Haraf and R.M. Kushmeider (eds.), Restructuring Banking and Financial Services in America. Washington, DC: American Enterprise Institute for Public Policy and Research.

. 1998. "Why financial stability depends on price stability." in G. Wood (ed.), Money, Prices and the Real Economy. Northampton, UK: Edward Elgar.

Seccareccia, M. 1988. "Systemic viability and credit crunches: An examination of recent cyclical fluctuations." Journal of Economic Issues 22(1): 49-77.

Segoviano, M.A., and C.A.E. Goodhart. 2009. "Banking stability measures.” International Monetary Fund, Working Paper No. 09/4.

Shiller, R.J. 1999. "Human behavior and the efficiency of the financial system." in J.B. Taylor and M. Woodford (eds.), Handbook of Macroeconomics, vol. 1c. Amsterdam: North-Holland. 
Sinai, A. 1976. "Credit crunches_-an analysis of the postwar experience." in O. Eckstein (ed.), Parameters and Policies in the U.S. Economy. Amsterdam: North-Holland.

Sinkey, J.F, Jr. 1977. "Problem and failed banks, bank examinations, and early warning systems: A summary." in E.I. Altman and A.W. Sametz (eds.), Financial Crises: Institutions and Markets in a Fragile Environment. New York: Wiley.

Stiglitz, J.E., and A. Weiss. 1981. "Credit rationing in markets with imperfect information." American Economic Review 71(3): 393-410.

Suarez, J., and O. Sussman. 1997. "Endogenous cycles in a Stiglitz-Weiss economy." Journal of Economic Theory 76(1): 47-71.

1999. "Financial distress and the business cycle." Oxford Review of Economic Policy 15(3): 39-51.

- 2007. "Financial distress, bankruptcy law and the business cycle." Annals of Finance 3(1): 5-35.

Suzuki, Y. 2005. "Uncertainty, financial fragility and monitoring: Will Basle-type pragmatism resolve the Japanese banking crisis?" Review of Political Economy 17(1): 45-61.

Thomson, J.B. 1991. "Predicting bank failures in the 1980s." Cleveland Federal Reserve Economic Review 27(1): 9-20.

Tymoigne, E. 2007. “Improving Financial Stability: Uncertainty versus Imperfection.” Journal of Economic Issues 41(2): 503-511.

. 2009a. Central Banking, Asset Prices and Financial Fragility. London: Routledge.

—. 2009b. "The U.S. mortgage crisis: Subprime or systemic?” in G.N. Gregoriou (ed.), Banking Crisis Handbook. London: Taylor and Francis.

. 2009c. "A critical assessment of seven reports on financial reform: A Minskyan perspective." Working Paper 574, parts 1-4. Annandale-on-Hudson, NY: Levy Economics Institute of Bard College.

Wolfson, M.H. 1994. Financial Crises, 2nd edn. Armonk, NY: M.E. Sharpe.

Wray, L.R. 2007. "Lessons from the subprime meltdown.” Working Paper 522. Annandale-onHudson, NY: Levy Economics Institute of Bard College. 